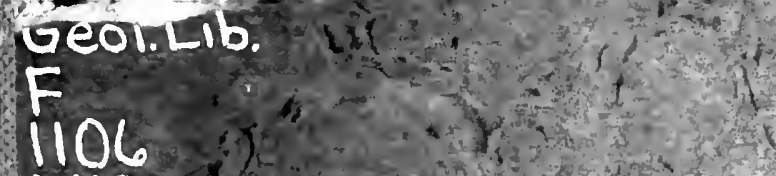 Misre
}
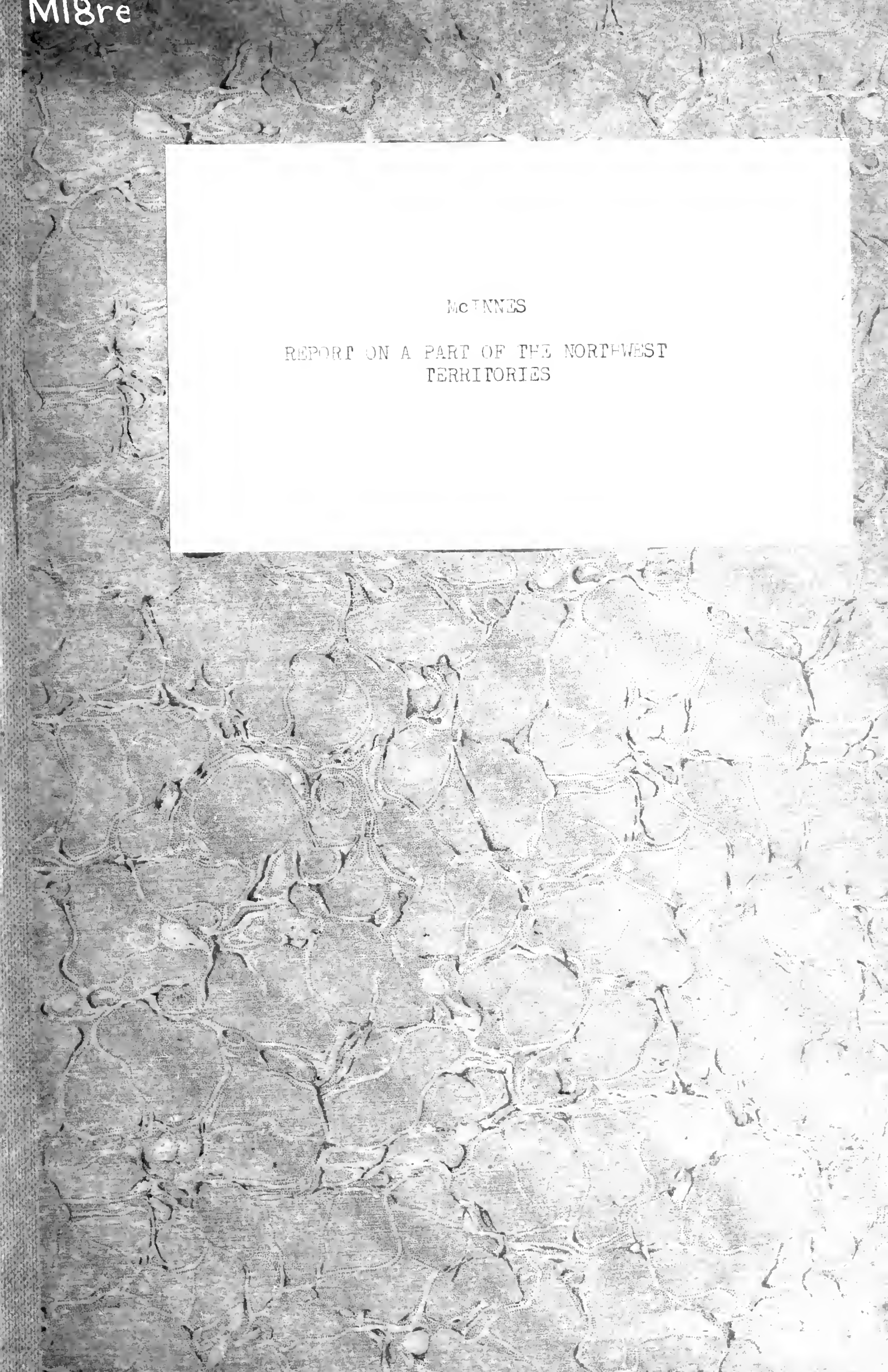


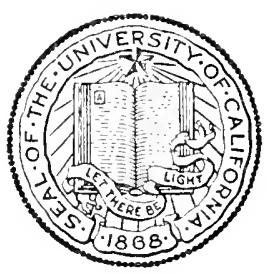

\section{THE LIBRARY OF}

\section{THE UNIVERSITY OF CALIFORNIA LOS ANGELES}

The RALPH D. REED LIBRARI DEP.ARTALNT OF GEOLOGY

LNIVERSITY OF CALIFORNIA LOS ANGELES, CIIIF. 


\section{DEPARTMENT OF MINES}

\section{GEOLOGICAL SURVEY BRANCH}

Hon. W. 'Templeman, Minister; A. P. Low, Defuty Minister:

R. W. Brock, DiRECTOR.

REPO R T

ON A PART OF THE

\section{NORTH WEST TERRITORJES}

DRAINEI) BY THE

WINISK AND ATTAWAPISKAT RIVERS

WILTIAM MCINNES

R EPOR T'

ON A

TRAVERSE THROUGH THE SOUTHERN PART

OF THE

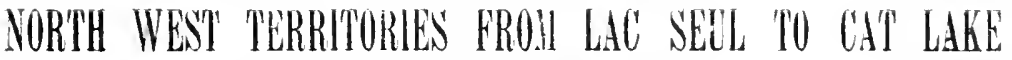

I $N \quad 190 \%$

$\mathrm{BI}$

ALFRED W. G. WILNON

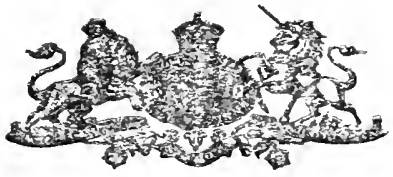

O T'T A WA

GOVERNMENT PRINTING BUREAL Sis 1910 
l 


\section{CANADA \\ DEPARTMENT OF MTNES \\ GEOLOGICAL SURVEY BRANCH}

Hon. W. Templeman, Minister; A. P. Low, Deputy Minister;

R. W. Brock, Drrector.

R E POR'T

ON A PART OF

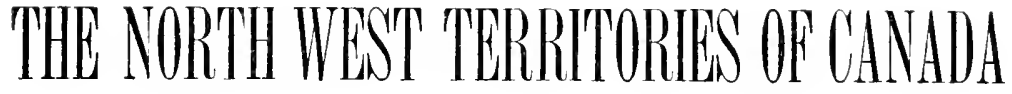

I)RAINEI IS THE

WINISK AND UPPER ATTAWAPISKAT RIVERS

BI

WILLIAM MCINNES

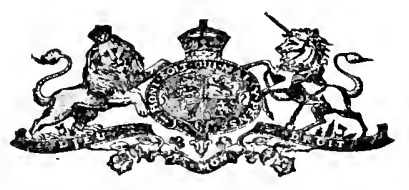

O T T A W A

GOVERNMENT PRINTING BUREAT

1909

$4074-1$

No. 1080 

谁 


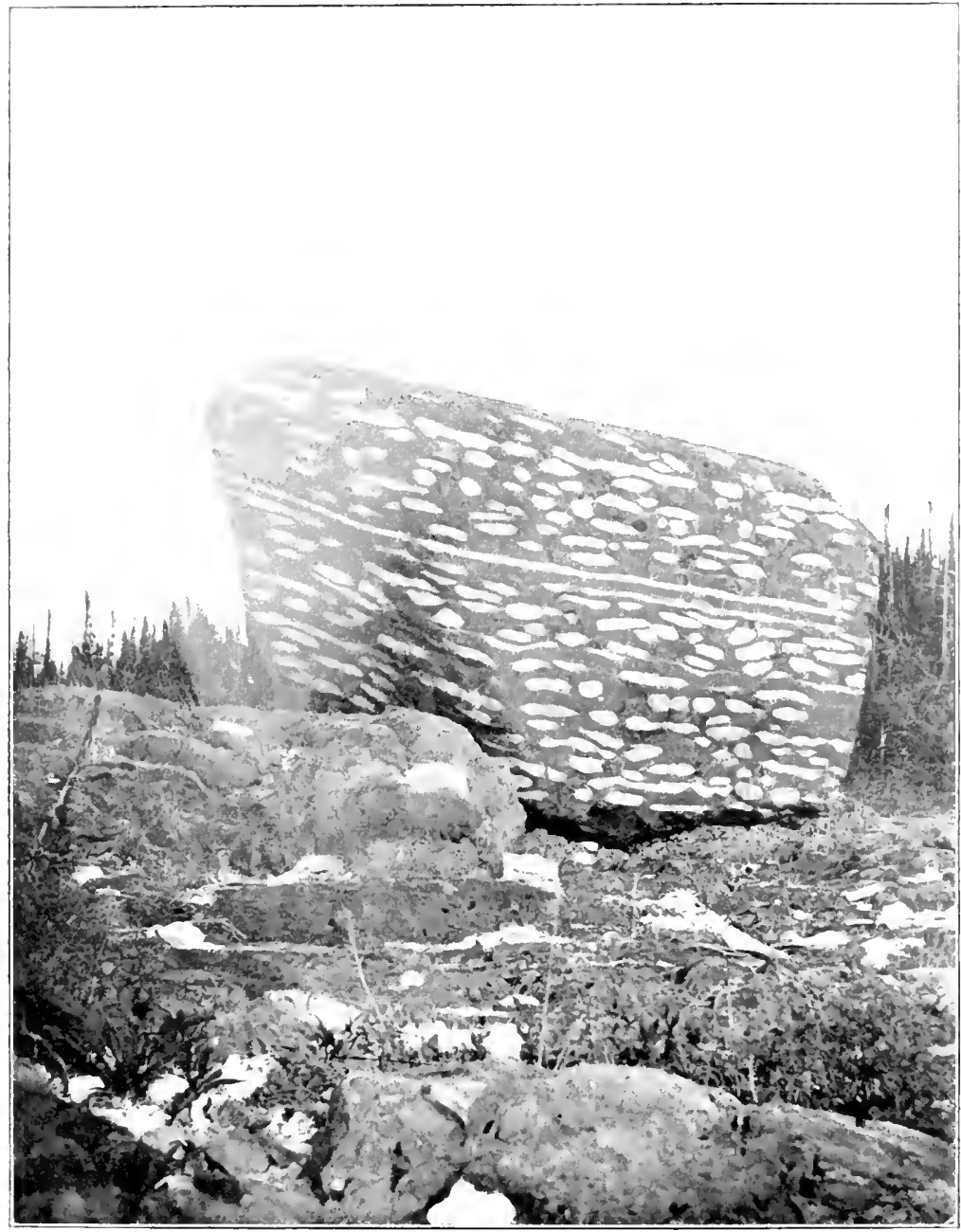

Bulkler of green and reddish-purple Slate, Winisk river. 
To R. W. Brock,

Director Geological Survey,

Department of Mines.

Sir,-I have the honour to submit a report on my surveys and explorations made during the seasons of 1903, 1904, and 1905, in the portion of the North West Territories of Canada drained by the Winisk river and by the upper branches of the Attawapiskat river.

I heve the honour to be, sir, Your obedient servant,

Ottawa, May, 1906.

\section{(Signed) WILLTAM MCINNES.}





\section{ONTENTS.}

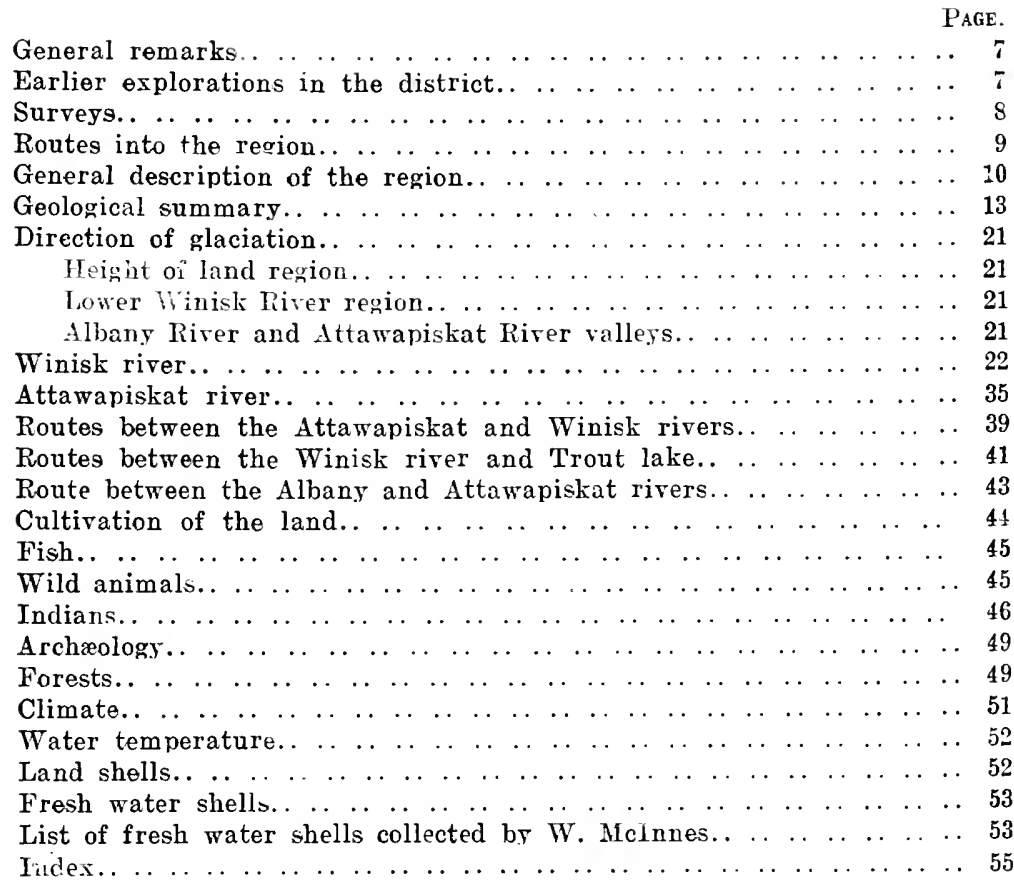

\section{ILLUSTRATIONS.}

Hlate I.--Boulder of green and reddish-purple slate, Winisk river..

Frontispiece.

"II.-Silurian limestone on the lower Winisk river.. . . . . . . 16

“ III.-Treeless area fringing west coast of Hudson Bay. . . . . . 34

" IV.-Indians of the lower Winisk river.. . . . . . . . . . . . . . 46

"V.-Lower Winisk river, showing banks of Silurian limestone, and characteristic forest.. . . . . . . . . . . . . . . 50

MAP.

No. 1089. Portions of Northern Ontario, and of che North West Territories, showing country drained by Albany, Severn, and upper Winisk rivers, etc. 



\section{REPORT ON A PART OF THE NORTH WEST TERRITORIES OF CANADA DRAINED BY THE WINISK AND ATTAWA- PISKAT RIVERS.

\author{
BY \\ William Micinnes.
}

The present report deals with a tract of country lying within the unorganized North West Territories of Canada, between $\mathrm{N}$. lat. $51^{\circ} 10^{\prime}$ and N. lat. $55^{\circ} 10^{\prime}$, and between W. long. $86^{\circ}$ and W. long $90^{\circ}$.

This district forms part of what was known for a time, prior to the inauguration of the Provinces of Alberta and Saskatchewan, as the District of Keewatin, and lies between the northern boundary of Ontario and the southwestern shore of Hudson bay.

It is drained by rivers running from the west into Jamies bay and into Hudson bay respectively, and the report is, in the main, a description of one of the latter-the Winisk-throughout almost its entire length, and of the upper branches of one of the former, the Attawapiskat.

\section{Earlier Exploration in the District.}

As far as $I$ have been able to learn, there are no references in the journals of the early explorer's to the Winisk river. All concerned in the search for a northwest passage to the Orient, they were naturally led to give most of their attention to the passages between the Arctic islands lying at the extreme north end of the bay. The mouth of the Severn river was, however, visited by a number of them, and Henry Hudson and Thomas James explored the bay now known as James bay, then called Hudson's bays.

Captain Thomas James, and Captain Luke Foxe (who styles himself in his journal, 'the northwest fox'), seem to have been the only navigators who sailed along the coast between the Severn rizer and Cape Henrietta Maria, for the purpose of examining it. They describe a generally low shore, with shallow water, and make no allusion to having noticed the mouth of the Winisk river. It must 
have been, however, as Mr. Miller Christy points out, in the vicinity of the bay at the mouth of the Winisk river that the two vessels approached one another in August, 1631, when the two captains, both bearing letters from His Majesty King Charles I to the Emperor of Japall, were able to compare notes as to their discoveries, and when Captain Foxe, ridiculing James' action in keeping his flag continually flying at the masthead, said to him, to use the quaint language of his journal, ' Ireepe it up then,' quoth I, 'but you are out of the way to Japan, for this is not it.'

Mr. G. Taylor, of the Hudson's Bay Company's service, seems to have visited the river in 1808, and to have supplied the topographical details that appear on the Arrowsmith map.

Dr. Robert Bell, in 1856, descended the Attawapiskat river from the lake, which he named Lansdowne, to the sea, and published an account of the exploration in the Annual Report of the Geological Survey for that year. ${ }^{1}$ The Fawn branch of the Severn river was explored by Dr. A.P. Low in $18 s 6^{2}$ and the Ekwan and Trout river: by Mr. D. B. Dowling and Mr. W. H. Boyd in 1901. ${ }^{3}$ No description of the Winisk has been published, though, without doubt, employes of the Hudson's Bay Company have traversed it, as, in the early part of the last century, posts of the Company were established at three points near the head of the river. The missionary priests from Albany, too, have descended the river, holding missions at the more important Indian centres.

\section{Surveys.}

In order to secure data for the compilation of a map of the region, the following surveys were carried out during the seasons of 1903-4-5 :-

Surveys by micrometer telescope and compass, checked by astronomical observations for latitude, were made of the Winisk river, from the muth to a point 190 miles from the coast following the course of the stream; from the foot of Wunnummin lake up to the outflow of the west branch at Misamikwash lake, a distance of 60 miles; down the west branch for 55 miles, and across by a portage route 24 miles in length to Trout lake at the head of the Fawn

1 Anmal lieport Geological Survey of Canada (New Series), Vol. II., 1866, Part G.

2 Ibid. Part E.

3 Summary Report Geological Survey of Canada, 1902. 
branch of the Severn river; of a route from the foot of Lake St. Joseph by way of the south branch of the Attawapiskat river to Fort Hope, a distance of 189 miles; and of 27 miles of the Albany river below Fort Hope.

In addition to the above a number of track surveys, checked by latitudes, were made. These covered portions of the Winisk river; part of the Attawapiskat river; three routes connecting the Attawapiskat and Winisk rivers; a route from the Albany river at Eabemet lake to Lansdowne lake; and a route from Trout lake down the west branch of the Winisk river and across to the main river near Nibinamik lake.

\section{Routes into the Region.}

While the number of possible routes to the Albany river from the Canadian Pacific railway is very great, there are but three that have been used to any great extent, one leaving the railway at Dinorwic station and reaching the Albany river by way of Lac Seul and its tributary the Root river, another one starting from Ignace and reaching the Albany by way of Sturgeon and Musibimega lakes, and another leading from Nipigon station by Nipigon river and lake and crossing to the Albany by way of the Ombabika and Opichuan rivers. The first of these is the best route in, particularly where a load is to be carried, as, though somewhat longer than either of the others, it is down stream or through large lakes for the greater part of the distance.

For light canoes and a quick passage the route by way of Nipigon is preferable, on account of the shorter distance to be traversed.

The greater part of the supplies used for the fur trade in the district are brought up the Albany river from James bay, a route including 300 miles of swift water where tracking is the only means of progression, and about 50 miles of alternating quiet water and rapids where portages are frequent. This is considered an easier route to Fort Hope, the headquarters of the trade, than any of the roads from the Canadian Pacific railway.

The completion of the Grand Trunk Pacific railway will shorten very considerably the distance from this side, and render the whole region comparatively easy of access.

From Fort Hope the heads of the Winisk and Attawapiskat rivers can be reached by several routes, none particularly difficult, but all made tedious by reason of the number of portages necessary. 


\section{General Description of the Region.}

The region may be roughly divided into three great areas, each with characteristic features: the Archæan area of the high interior plateau; the boulder clay area; and the limestone area of the Hudson Bay basin. The Archæan, of the three, comprises by far the largest extent of country. It consists of an elevated, undulating plain, with an average height of from 700 to 1,000 feet above sea-level. The effects of long-continued subaerial decay and denudation, supplemented by the later cleaning up and smoothing action of a great glacier, are everywhere noticeable in the gently rounded outlines of the very moderate elevations. On it all the larger rivers of the Hudson Bay watershed, and many of those flowing south and west, have their sources, the great muskeg areas acting as storage reservoirs, from which, even in the dryest season, the volume of drainage is large. It is along the parts of their courses lying within this area that the quickest descent occurs, falls and rapids that would afford water-powers being thus largely confined to the upper stretches of the streams. This condition is in contrast with that obtaining everywhere throughout eastern Canada, where the streams flow for the greater part of their length over the Archæan, and only come tumbling down from the elevations when low down in their courses after they have attained almost their maximum volume, thus making the eastern portion of Canada probably unequalled in the world in the matter of water-powers. It must not be thought, however, that throughout the area now under consideration there is any scarcity of good water-powers. They occur in great number, but owing to the distribution of the Archæan highland before referred to, they are situated mainly far inland rather than near the coast.

Though, considered as a whole, the central, elevated region cannot be spoken of as generally adapted for agriculture, there occur basins corered by heavy deposits of stratified sand and clay that seem to have been laid down in lakes held in between barriers formed by the walls of the retreating glacier and ridges of drift. An examination of some of these clays by Dr. Hoffmann shows them to be highly calcareous and somewhat siliceous, a composition that with the admixture of the surface regetable mould should produce an excellent soil for general agriculture. The question of climate, which is, of course, of the utmost importance when considering the agricultural possibilities of a district, will be referred to more particularly 
in another place. It may be said here, however, that the climatic conditions are, if somewhat adverse, not by any means prohibitory to the general cultivation of suitably situated tracts.

Muskeg, alternating with low ridges of gravel and boulders, covers wide tracts, though, owing to the fact that the only practicable mode of travel through the country is by canoes, there is a tendency, perhaps, to overestimate the extent of such areas, as the natural canoe routes must follow the watercourses, and these in turn keep to the lowest elevations, and, therefore, show a proportion of swamp that is greater than the average of the district. It was noticed that the surface drainage became more perfect in that part of the region extending westerly towards Trout lake. Ascending the Winisk river from Weibikwei lake towards its headwaters this was very noticeable, the muskeg areas becoming infrequent and of smaller extent.

The larger lakes throughout the district are confined to the Archæan area. They are all comparatively shallow, and so studded with islands, and broken by long, projecting points, that they seldom show any large expanses of open water. They occupy depressions in the superficial deposits, generally with a boulder clay bottom, and in no case was one found occupying a regular rock basin.

The areas of the principal lakes are approximately as follows:-

Wunnummin lake. . . . . . . . 60 square miles.

Weibikwei lake. . . . . . . . . . . . . 4040 "

Lansdowne lake. . . . . . . . . . . . . .

Ozhiski lake. . . . . . . . . . . . . . 25 “

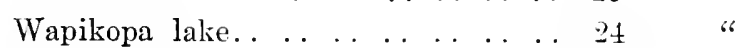

Eabemet lake. . . . . . . . . . . . . . . 20 "

Nibinamik lake. . . . . . . . . . . . 10 10 "

The highest land lies about the headwaters of the south branch of the Attawapiskat river, east of Cat lake, where an elevation of probably 1,500 feet above the sea-level is reached.

The approximate heights of the principal lakes determined by barometric measurement is given below:-

Eabemet lake, Albany river. . . . . . . . 900 feet above sea-level.

Ozhiski lake, Attawapiskat river. . . . . 910 " " "

Lansdowne lake, Attawapiskat river. . . $815 \quad$ " " "

Wimbobika lake, Attawapiskat river. . . 1,300 " " " " "

Weibikwei lake, Winisk river. . . . . 670 " " 
Wapiliopa lake, Winisk river.. . . . . 750 feet above sea-level.

Nibinamik lake, Winisk river. . . . . . 785 " "

Wunnummin lake, Winisk river... . . 830 " "

Misamikwash lake, Winisk river.. . . . 865 " "

The tract referred to as the boulder clay area consists of a broad belt of country, about 159 miles in width, lying between the Archæan highlands and the edge of the limestones of the basin of Hudson bay, overlapping the latter, however, so that the surface features of the two are generally quite similar.

Gently undulating, and with a slight slope northerly and easterly, its general surface aspect is that of a great swamp, sparsely covered with stunted and deformed trees, that reach a growth approaching their normal only along the immediate banks of the rivers where drainage is afforded by frequent short gullies into the trenches that constitute the river valleys. The interior, to within a chain or two of the river-banks, owing to the impervious character of the till, is quite undrained, and consequently covered by a thick deposit of sphagnum moss from two feet to ten feet deep, the surface layer still growing, and eren the bottom only bleached a little, but not at all oxidized. The short cool surnmer season, and consequent low temperature of the water that saturates the moss, is probably the principal reason for the absence of any of the visible effects of decay.

The rivers flowing through this region have no real valleys, that is to say, they occupy trenches but little wider than the immediate channels in which they flow, cut down through the stiff, tough till, which stands up in nearly vertical walls that rise from the freshet mark on either side. At low stages of the water a slanting beach, often paved with boulders, slopes gradually from the foot of the bank to the edge of the diminished channel. A more or less continuous layer of marine clay, rich in fossil shells, overlies the boulder clay, ensuring, wherever it is present, a soil of good quality. The absence of other than swamp vegetation must be ascribed, then, to the almost total absence of drainage, and to the generally unfavourable climatic conditions.

The third area, underlain by Silurian limestones and dolomites, presents essentially the same surface features as the till area. The folding of the limestones, however, though generally amounting to broad undulations only, gives to it somewhat more of relief, and the troughs in which the rivers lie have been excavated entirely through 
the mantle of till, and have cut down into the limestones to depths of from twenty to thirty feet.

There is the same absence of any vegetation other than that having a muskeg habitat, excepting on the islands in the rivers and along their banks.

The northern rim of this area consists of a treeless plain, bordering the shores of the bay, and varying in width from a mile and a half to three miles. It has an elevation of only a few feet above the level of high, spring tides, and is probably submerged on occasions when these tides happen to coincide with northeast storms on the bay. The sandy and gravelly surface is sparsely covered with bunchy grasses, and, early in August, was bright with the flowers of many sub-arctic plants, among which the Aretic daisy, Chrysanthemum arcticum, the yellow ragwort, Senescia pallistris, the painted cup, Castelegia pallida, a live-for-ever with small, bell-like blue flowers, purple vetches, and the large rose-coloured Epilobium were prominent.

\section{Geological Summary.}

The geological divisions recognized in the region under consideration consist of the following, in ascending order:-

\section{Laurentian.}

Keewatin,

Lower Huronian (?),

Silurian (Niagara),

Pleistocene (Till, etc.),

Post-pleistocene (Marine clays, etc.),

LAURENTIAN.

Biotite granite gneisses, varying in the proportion of their various constituents, in their attitude, and in the degree to which the gneissic structure has been developed in them, are widespread over the whole extent of country explored. Over great areas they have a stratiform appearance, the foliation showing an almost horizontal structure, with only very low, broad undulations. As at present constituted they, without doubt, include areas that differ widely in age, the comparatively new granites, however, occurring in quantity quite insignificant in comparison with the volume of the older gneisses. Pegmatites, in veins and irregular masses, cut the gneisses practically everywhere, and are, probably, though newer than the gneisses, almost contemporaneous with them in their present form. 


\section{KEEWATIN.}

The Keewatin bands, made up of areas of basic rocks, in the main diorites, diabases, and chloritic and hornblende schists, but including a considerable volume of coarse conglomerates, though occurring as belts of considerable length and four to six miles in width, are of excecdingly small volume when compared with the whole extent of gneisses in which they are enfolded. Probably not more than a tenth of the whole Archæan area is occupied by them.

In the region explored, between the Albany river and the overlap of the mantle of till, six apparently separate belts of these rocks were noted. They have all, in a general way, about the same trend, N. $70^{\circ} \mathrm{E}$.

The belt of these rocks crossing the Albany river at Petawanga lake and seen again on the route between the Albany at Fort Hope, just north of Eabemet lake, is the most southerly. It is made up for the most part of chloritic, feldspathic and hornblendic schists, and diorites in different stages of deformation, and has a width of about six miles. The gneisses bordering the belt on the south are finely foliated, hold a large proportion of black biotite, and are, in certain layers, thickly spotted with garnet crystals. Masses of coarse pegmatite, cutting these gneisses, hold crystals of mica up to $2^{\prime \prime}$ in diameter.

The next belt going northerly is situated about twenty miles north of the Albany river, and is well exposed along the banks of the Kawinogans river, which has cut its channel in these rocks for about seventeen miles. This band is from one to four miles in width, and is made up of feldspathic and chloritic schists, diorites and other basic rocks. It is flanked by biotite gneisses, with, at points close to the contact, occasional outcrops of hornblende granite-gneiss.

Another belt, quite similar to the two above referred to, lies just north of Lansdowne lake. Further reference is made to it in the descriptions of the routes leading north from the Attawapiskat to the Winisk. The most interesting belts are the next two; the first, lying just south of Nibinamik lake, by reason of the occurrence in it of a large mass of hypersthene gabbro, similar to the nickel-bearing intrusives of Sudbury; and the next, the Wunnummin Lake band, on account of the extensive development in it of heavy beds of coarse conglomerate, holding pebbles, chiefly of various forms of granite. The most northerly band is apparently quite narrow, and was noted 
only where a few isolated outcrops are seen near Kingfisher lake north of the Winisk river.

SILURIAN.

The Silurian section along the Winisk river seems to comprise, in ascending order, twenty feet of close-grained, hard, brittle, green and black ribboned slates, with bands and nodules of more highly calcareous material; six feet of a hard, dark-grey, rusty weathering, calcareous quartzite; ten feet of a much more calcareous form of the last named beds, so calcareous as to constitute an impure limestone rather than a quartzite. All of these lower beds, which are exposed at but one place on the river, where they are brought up by a compound anticlinal fold, are hard and baked-looking, with many small veins of quartz and calcite cutting them in all directions. Lithologically they are quite dissimilar to any of the strata composing the rest of the section. Further effects of pressure are seen in the hardened condition of all the rocks, and in their cracked and fissured condition, the cracks filled with secondary quartz and calcite. The more massive beds described as calcareous quartzites are seamed in all directions by these white, reticulating veins, which are bought into strong prominence by their contrast in colour with the dark, rusty-weathering surfaces of the parent rock.

There seems to be a gradual passage upwards from these beds, by the increase in their calcareous content, into impure limestones, and then into the next beds in the series, consisting of a series of slightly magnesian limestones, comprising eight feet of buff-coloured, slightly ferruginous, hard, close-grained, flaggy beds, with the texture of lithographic stone in certain layers; two and a half feet of more massive nodular limestone, the nodules of finer texture than the enclosing, slightly shaly matrix; and ten feet of rubbly, shaly limestone, with occasional sandy layers. Nodules of bluish opalescent quartz, with banded, agate-like structure, occur in the more compact beds throughout the series.

Above these beds is a very persistent band, six feet in thickness, of a tufaceous-looking, vesicular limestone, the very distinctive character of which makes it easily recognizable at many points along the river. Cavities in it are coated with crystals of calcite, and vesicles and cracks occurring in it are filled with a fibrous form of that mineral. The calcite occurs throughout the rock in irrregular masses that weather out to form cavities of irregular sizes and shapes. 
Immediately above this bed there occurs a $6^{\prime \prime}$ layer of a compact . ellowish limestone, with but little magnesia; then six feet of very fine-grained, almost compact, very light buff coloured dolomite, containing a small quantity of argillaceous matter and occurring in heavy flag-like beds, the plates hard and clinking under the hammer. These are overlaid by twelve feet of buff-coloured impure magnesian limestone, shaly in certain layers; and ten feet of flaggy and shaly buff-coloured, somewhat nodular, magnesian limestone, the whole becoming disintegrated easily so as to show only nodular, crumbling surfaces.

Broadly speaking, the strata may be said to lie almost horizontally, with a slight dip towards the shores of the bay, amounting to about the same as the descent accomplished by the river. Low undulations cause the same beds to recur again and again in the sections exposed along the river. The exposures are not continuous, long intervals where the overlying boulder clay only is seen intervening between the exposed sections, so that the generalized section given above, and tabulated on a succeeding page, is made up from an examination of separated exposures occurring along the river for a distance of eighty miles. Though the strata are uniformly buffcoloured and closely similar in general appearance, a few very distinctive beds-notably the tufa-like limestone bed, which seems to be very persistent and to keep its distinctive characteristics-serve to connect the various exposures satisfactorily. The lowest beds, comprising the thirty-five feet of strata brought up by the compound anticlinal fold, appear at only one place on the river. As no fossils were found in them their age can be inferred only from their apparently conformable position immediately underneath the fossiliferous Silurian strata.

The corrugated surface of the dome of the anticlinal itself dips about ten degrees north of west, at a low angle varying from five to twenty degrees, and it is possible, though not probable, that the rocks noted by Mr. Dowling at Sutton Mill lake represent underlying beds brought up by a southeasterly extension of this fold.

The calcareous nodules, which probably represent bands broken by the stress of the folding, weather out readily, where exposed to atmospheric action, leaving a rock full of holes. 


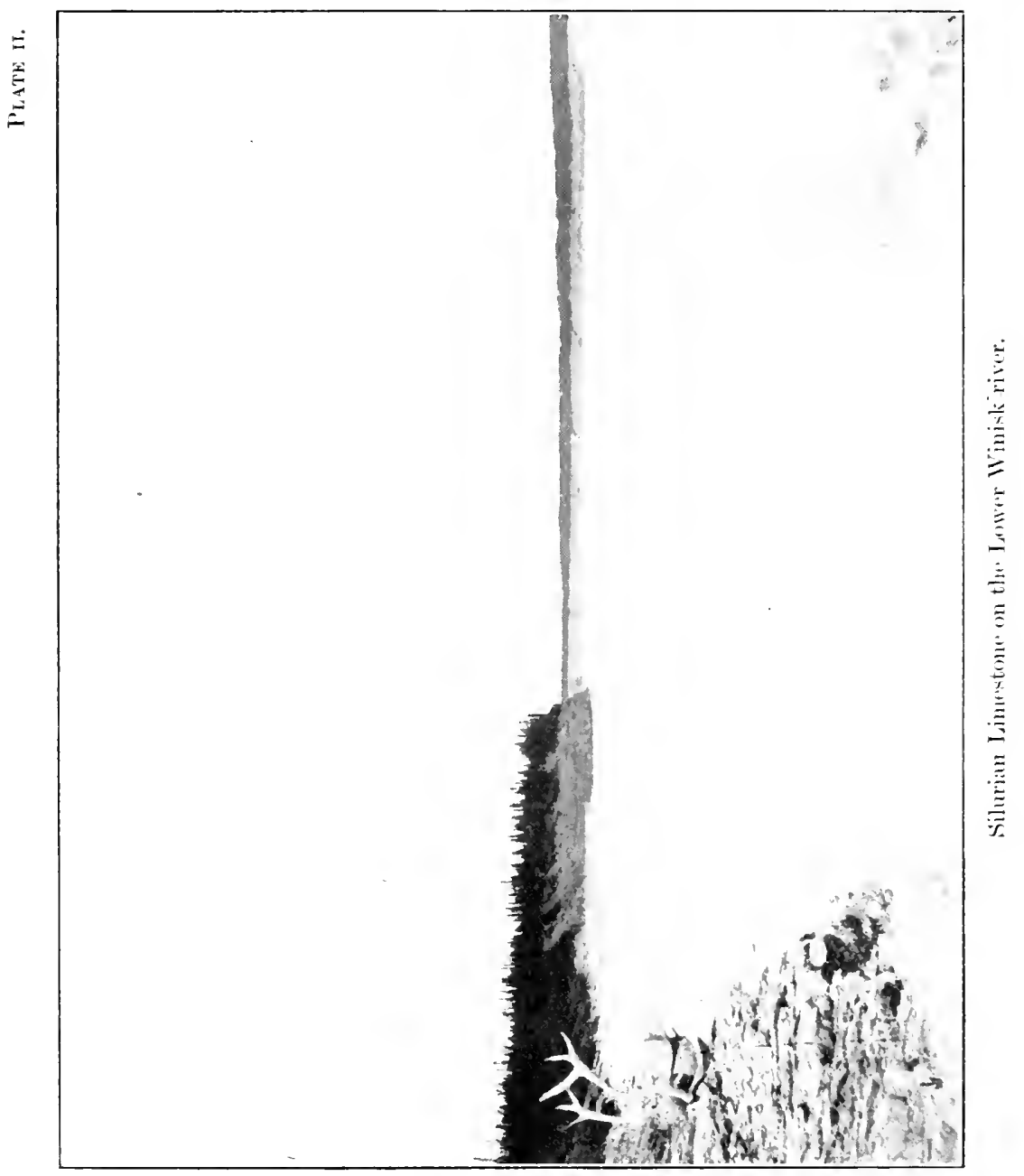

$4071-1.16$. 

GENERALIZED SECTION ALONG THE WINISK RIVER.

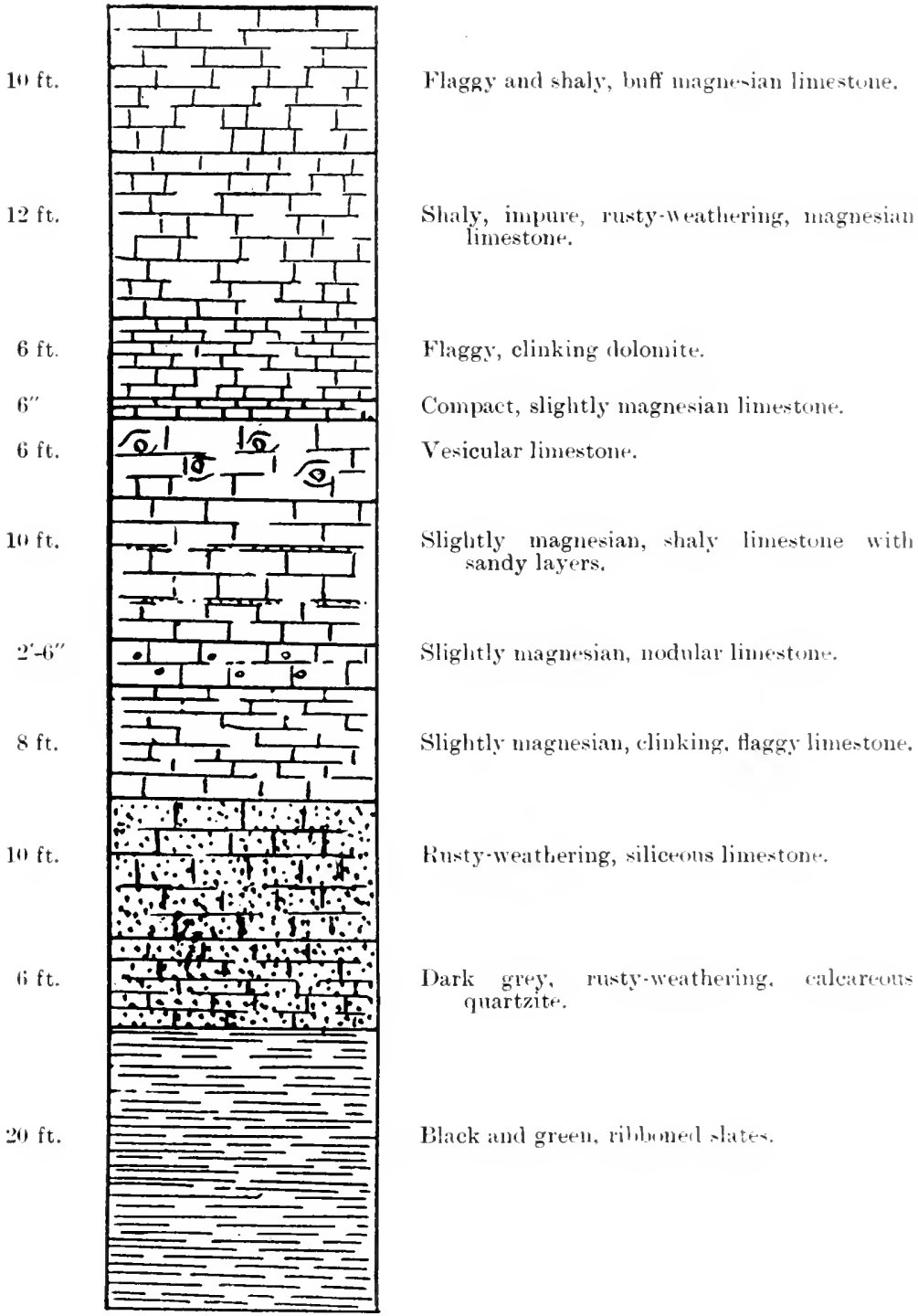

$40-1-2$ 
A small collection of fossils was made from the beds overlying the resicular band, in which Dr. Whiteares has identified the following forms :-

Favosites gothlandica, Lamarch.

Stropheodonta niagaraensis, W. and Mr.

Leptana rhomboidalis, Wilckens (sp.).

*Camarotochia (?) winishensis, Whiteaves.

*Camarotcchia (?) coalescens, Whiteares.

*Glassia variabilis, Whiteaves.

*Actinoceras keewatinense, Whiteares.

Trimerella, sp. indet.

Orthis,

Spirifer,

"

Streptelasma, "

Trochonema, "

Euomphalus, "

Loxonema, " "

Cyrtoceras, "

Bronteus, " "

Encrinurus, "

Though not a very satisfactory collection in itself for purposes of age-determination, the abore-named species correlate the beds holding them with those of the Serern rirer to the north, and the Ekran river to the south, and collections from the three localities combined fix the age of the rocks very satisfactorily.

The southern limit of the Silurian limestones cannot be fixed with any degree of exactness, oring to the heary orermantle of till that conceals from view the underlying rock for a distance of 130 miles along the river. It seems probable, however, that it extends to the vicinity of N. lat. $54^{\circ} 20^{\prime}$. Mr. Low found on the Fawn branch of the Severn, the nearest river to the west, the same wide area of country completely covered by till interrening between the most northerly exposure of gneiss and the first exposure of limestone. $\mathrm{He}$ thought it probable that the limestones extend under the till for a distance that would correspond rers closely to that given above for the Winisk. East of the Winisk river the inland boundary of the Silurian bends suddenly to a direction nearly due south, crossing the

* The two new species of Camarotachia, the Glassia and the Actinoceras have been described by Dr. Whiteares in Palrozoic Fossils, Vol. III., Part IV., 1906, where further notes concerning the collection will be found. 
Attawapiskat river a little abore $\mathrm{N}$. lat. $52^{\circ} 30^{\prime}$, and the Albany one degree lower.

\section{PLEISTOCENE.}

The boulder clays of the Winisk rive: may be easily divided into an upper and a lower till, the one lying upon the gently undulating surface of the other.

The upper bed is composed of a buff-coloured clay, drying slightly friable, with occasional large boulders, and many small pebbles and angular fragments of diorite, quartzite, gneiss, red and white sandstone, jasper, etc. Its greatest obserred thickness is about forty feet, measured from the surface of the lower till to the bottom of the fossiliferous marine beds. No stratification is apparent in it, and the large boulders are so rare, that, at a little distance, cut faces have the appearance of beds of pure clay.

The lower till, the thickness of which was not ascertained, is composed of an extremely tough blue clay, with very many large boulders, semi-rounded and mostly well striated. Limestones and dolomites quite similar to the Silurian beds of the lower river make up a large proportion of the boulders, but others of gneiss, quartzite conglomerate, etc., are not uncommon. The sloping beaches extending between low and high water marks are often a mosaic of the washed out material from the clay, forming very good examples of boulder pavements, the natural tendency of the rocks to arrange themselves with their flatter sides parallel to the surface resulting in an almost smooth floor, over which the spring floods seem to pass with little or no denuding power. The whole bed of the river is, in the same way, protected by a laver of heavy boulders that offers great resistance to the wear of the current, and that has practically stopped the further excavation of the chamel at lerels far from the bottom of the lower till.

The accumulations of glacial drift are an important feature over this whole district. They form the highest elerations, and are the principal causes that define the shapes of the lakes and the directions of the rivers. The influence of morainic ridges of boulders and gravel on the course of a rirer is strikingly seen in the case of the upper part of the Winisk river. The direction of the ice movement was about S. $23^{\circ} \mathrm{W}$., and the course of the river is found to conform to this direction to a remarkable extent, that is, it makes its war 4074-21 
eastward in a series of zig-zags, the lake-like expansions conforming in a remarkable way to the course of the morainic ridges of drift.

The lakes occurring along the river are characterized by many long narrow bays with the same trend, due to the drift ridge that bound them.

The glaciation of the whole area shows most clearly that it is the result of the passage of a lirge glacier, continental almost in extent, moving in a general way a little south of west, but showing minor detlexions, that oceurred probably at stages in the period of glaciation when the ice sheet was not at its greatest thickness and was more readily influenced by the surface contours.

The general S.S.W. direction of movement is indicated not only by strix, chatter marks, and crag and tail sculpturing, but also by the character of the boulders enclosed in the till and scattered broadcast over the Archean area. The occurrence of the fossil-bearing limestones along the west coast of Hudson bay and James bay, and the entire absence of any rocks at all similar to them over the whole region farther south, makes the character of the travelled boulders derived from these rocks a sure index to the direction followed by the moving ice-sheet. Additional evidence is afforded by the occurrence in the till of boulders and pebbles of jasper, hematite, quartzite of a very distinctive character that $\mathrm{D}_{\mathrm{i}}$. Bell has recognized in place on the east coast of Hudson bay, and jasper breccia or conglomerate. The wide tract of country lying between the Archiean gneiss and the first exposures of limestone, where the underlying rocks are completely concealed by the thick mantle of boulder clay, might be the source from which is derived many or all of these apparently foreign boulders, but their very close similarity to rocks that are known to oceur on the east shore of Hudson bay makes it more probable that they have been derivel from them.

I few southwesterly stria that appeared to be possibly later than the prevailing ones might be interpreted to indicate a glacier travelling down a gathering ground such as has been assigned to the Keewatin glacier. The local variations of the striæ from the general direction are so many, howerer, that it seems quite possible that they are only the records of deflexions caused by local surface relief, and made wohns ly a very much reduced glacier. No evidence of a glacier moving down towards the hay was noticed. The following list of whoial striat is arranged under three divisions-the height-of-land 
region where the stria may be eonsidered to represent most truly the general eourse of the glaeier, the Winisk River ehamnel where the direetion of the stria seems to have been somewhat affected by the river course, and the valleys of the Albany and Upper Attawapiskat rivers, where the direetion has been quite governed by the trent of the valleys.

\section{Direction of Glaciation.}

\section{Height-of-Land Region--}

Kawinggans river................. $\ldots$ S. $50^{\circ} \mathrm{W}$.

Hail lake. . . . . . . . . . . . . . . . . . S. $40^{\circ} \mathrm{W}$.

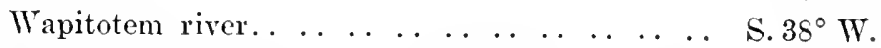

Winisk river, eight miles above Weibikwei lake. S. $35^{\circ} \mathrm{W}$.

Winisk river, Wapikopa lake.......... S. $32^{\circ} \mathrm{W}$.

Louer Winisk River Region-

Winisk river below outflow of Winiskisis..... S. $6^{\circ} \mathrm{W}$. at outflow of Tabasokwia..... S. $6^{\circ} \mathrm{W}$. above Tashka rapid. ...... S. $10^{\circ} \mathrm{W}$. at Tashka rapid......... . S. $30^{\circ} \mathrm{W}$. at Boskineig fall... ... . . . S. $30^{\circ}$ E. $\frac{1}{4}$ mile below Boskineig fall ... S. $18^{\circ} \mathrm{W}$. 1 " " $\quad$ " 2 miles " $\quad$ " $\quad \ldots \quad$ S. $12^{\circ} \mathrm{E}$.

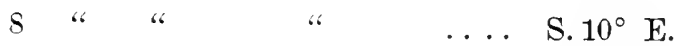

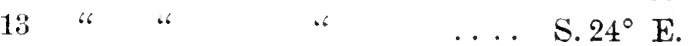
$15 \quad " \quad * \quad * \quad \ldots \quad$ S. $26^{\circ}$ E.

Albany River and Attawapiskat River Talleys-

Eabemet lake, northwest shore. . . . . . . $\$ .83^{\circ} \mathrm{W}$.

“ north shore.. . . . . . . . . S. $78^{\circ} \mathrm{W}$

Albany river 10 miles below Eabemet..... S. $68^{\circ} \mathrm{W}$. " $12 \quad$ " $\quad 12 \quad$ " $\quad \ldots \ldots \ldots$, S. $67^{\circ} \mathrm{W}$.

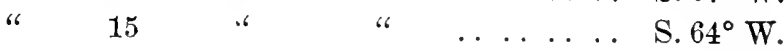

Ozhiski lake. . . . . . . . . . . . . . . . . . W.

Kabania lake. . . . . . . . . . . . . . . . . . . N. $79^{\circ} \mathrm{W}$.

POST-PLEISTOCENE.

The marine elays, overlying the boulder clays aloug the Winisk river, were found to be generally fossiliferous, excepting near their most southerly extension where the $y$ are quite thin, and, as far as 
olserved, do not hold fossils. From a collection made from these eliys in 1903, Dr. J. F. Whiteavis has identified the following sprecies :-

Pecten islandicus, Mïller.

Mytilus edulis, $\mathrm{I}$.

Cardium ciliatum, Fabricius.

Serripes Gronlandicus, Gmelin.

Macoma calcarea, Gmelin.

Mya truncata, L.

Mya arenaria, $\mathrm{L}$.

Saxicava rugosa, I.

Buccinum tenue, Gray.

Buccinum ?

and, fresh water species:-

Spharium slriatinum, Lamarek.

Limnre palustris, L.

\section{The Winisk River.}

The Winisk river, though without falls in its lower course, and with a volume that would lead one to suppose it easily navigable by vessels of considerable size, is so rapid and so wide for a long distance up from the bay that it would be difficult to find a channel for a steamer of even moderate draft. This is particularly true of the thirty miles of its course over the flat-lving limestone ledges that often form barriers quite across the river bed, on which there is a depth of only a few feet of water.

The river has cut down into the limestones to a depth of more than forty feet, the strata rising in vertical walls to that height above mean low water level.

There is evidence that the river followed its present channel in the limestones prior to the glacial period. It has since then not worn out for itself any valley beyond its immediate channel, which is a niere trench in the boulder clay in the upper stretches, and in the clay and underlying limestones farther down. The extreme toughness of the lower boulder elay, and the protection afforded by the great number of large boulders that wash ont from it and coat the bottom and lower parts of the sides of the trench, have prevented any quick degradation of the banks, which stand up, raw and steep, like the sides of a newly exeavated canal or railway cutting. The 
more gently sloping parts of the bank, between high water mark and the foot of the boulder clay wall, are covered with a growth of grasses and small bushes, and, beyond latitude $54^{\circ} 30^{\prime}$, the nearly vertical boulder clay itself supports a growth of silver berry, Eleagnus argentea, and bufle berry, Shepardia, the almost snow-white foliage of the former standing out in strong contrast with the dark-green leaves and red berries of the latter.

The Winisk river, along its upper course easterly to Weibikwei lake, has a distinguishable valley. The lower part of the river, however, from the lake to the sea, has absolutely no valley outside of the steep-walled trough in which it runs. The upper Attawapiskat river, flowing in an easterly direction, has a fairly well-marked ralley, comparable to that of the Albany, though of less extent. The upper parts of the river are roughly parallel to one another and to the Albany river, with which it is not at all improbable that the Attawapiskat was at one time connected, as the eountry now dividing them is characterized by high hills of glacial drift, filling up and concealing any former channels that may have existed. These are the very remarkable hills described elsewhere in this report in greater detail.

In all the rivers on this slope is seen the tendeney to split up into two or more clannels, enclosing areas of land often many miles in extent. This feature is more marked in the case of the Winisk than in any of the others. Above Weibikwei lake one of these divisions of the channel oecurs, enclosing an area of thirteen square miles; and below, the two branches known as the Winiskisis and the Tabasokwia flow around islands with areas of about 480 and 180 square miles respectively. The former of these branehes, flowing to the east at a point seven miles below the lake, joins the main river again sixty-five miles below. The Indians say that no important stream comes in to the branch, but a number of small streams makes it a river of considerable size at its confluence with the main channel, even at low water when no water is passing over the bar at its upper end.

The volume of water in the river during the period of spring freshet must be quite ten times as great as at low water in midsumner. The height reaehed by the water is, in many places, plainly indicated on the banks.

Evidences of the destructive force of the ice, when running out in the spring, are common. Trees on some of the islands are found 
broken and uprooted at heights of fifteen feet above the normal water level, and the boulder elay of the banks is ploughed and deeply scored at corresponding heights.

The flat surface of the limestone bordering the gorge is eridently swept annually by the river when at its height, though the water surface in the gorge at ordinary summer level is thirty feet below the top of the limestone.

No beds of lignite were observed, though a few highly carbonaceons, sandy layers were seen to occur at water level, apparently beneath the boulder clay on the upper Winisk river.

Owing to the frequent small landslides oceurring along this part of the river it was impossible to fix the position of these beds with any degree of certainty.

Though for so great a part of its course the river is bordered by high and steep banks of clay, landslides seem to be exceedingly rare, excepting where the country has been swept by forest fires. Where fires have recently taken place along the banks, denuding them of their protecting vegetation, small landslides are almost continuous.

The Winisk is with little doubt the largest of the rivers discharging into the west side of Hudson bay or James bay between the Severn and Albany rivers. Rising in the highlands lying to the south of Trout lake, it drains the large expanse of country lying to the east of the upper waters of the Severn river, and to the north of the spreading branches of the Attawapiskat. The watereourses of this section of country have been most inadequately represented on the existing maps, owing to the lack of knowledge of their positions, and a reference to the map accompanying this report will be neeessary in order to understand the apportionment of the watersheds among the various rivers. From Misamikwash lake, above which the Winisk is divided into two main and many smaller branches, the river flows out by two ehannels, one quite insignifieant in rolume flowing to the north, and the other, a river of considerable size, flowing to the east. The former of these forms the head of the Asheweig or west branch of the Winisk, and the latter the main river.

Diverging at a point situated in N. lat. $53^{\circ}$ and W. long. $90^{\circ}$, these two streams unite 224 miles below, following the course of the main river, in N. lat. $54^{\circ}$ and $\mathrm{W}$. long. $57^{\circ} 50^{\prime}$.

From Misamikwash lake for twenty-fire miles the river lieeps a general easterly course. In this distance the descent is about thirty- 
five feet, and occurs principally in a series of five rapids, at the lowest of which, just above Wumummin lake, there is a very considerable fall. Between the rapids are stretehes of swift water, raried by many lake-like expansions. The surrounding country is for the most part low, seldom rising to greater heights than fifty feet above the river. Few rock exposures are seen, what there are consisting of low, rounded knolls and ridges of well foliated biotite granite gneiss, generally with an almost horizontal foliation and often inraded by a coarser white granite or pegmatite. The banks are usually low, but in places the river is found impinging against a bank of unstratified sand and gravel twenty to thirty feet in height.

Below the rapid and fall just referred to a large stream comes in from the south, and the river widens out to form Wumummin lake, a body of water of varying width, twenty-five miles in length. The trough in which the lake lies has been hollowed out mainly in a band of Keewatin rocks to whose trend it generally conforms. The most conspicuous rocks occurring in the belt are heary beds of coarse conglomerate, very similar to that of Abram lake on the English river below Mimnitaki lake. ${ }^{1}$ With these are associated diorites and chloritic and hornblende schists, the whole striking about N. $70^{\circ}$ E. and dipping at high angles. These rocks can, without doubt, be classed almost wholly with the Keewatin, though there are possibly small areas of lower Huronian, the basal beds of which would be represented by the conglomerate.

About the lake almost the only eminences in view are low hills of unassorted drift, rising generally not more than fifty feet above the water level, but in one case forming a very striking cone-shaped eminence, rising perlaps 300 feet above the surrounding level. Owing to its inaccessibility this hill was not visited, but from its general aspect, and from the accounts of it given by the Indians, it evidently is one of those remarkable, isolated masses of drift seen on the south branch of the Attawapiskat, and noted also by Mr. Camsell as occurring in the country north of Cat lake. ${ }^{2}$

From Wunnmin lake to Nibinamik lake, a distance of twentyfive miles, the descent is about forty-fire feet, the fall occurring principally at three points, where series of heary rapids break the course of the river. Between these are stretches of quict flowing

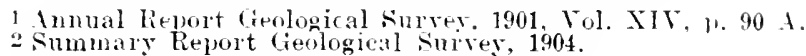


water, where the current, though generally strong, flows along placidls between banks of sand not generally high, but in places, where the current has worn into the side of a drift ridge, showing cut banks serenty-five feet in height. A stream known as Michikenis flows in from the south about six miles below Wunnummin lake, and a larger cne, referred to again in describing the route from Trout lake, joins the ricer from the north five miles above Nibinamik lake.

Nibinamik lake is an irregular body of water whose shape has been largely defined by ridges of glacial drift. From inlet to outlet is but five miles, the lake, however, extending to the south for seven miles and to the north for four miles. A number of low ledges of fine, well-foliated biotite gneiss occur along its shores, cut by a coarse white gneiss that often is interbanded with the finer, giving the whole an appearance of stratification. The land rises gradually from the lake shores to heights of abont sixty feet, a considerable thickness of sand and gravel concealing the underlying rocks, excepting at the immediate shores. A forest about one hundred years old, but never very large, covers the surrounding country. Spruce and tamarack are the principal trees, with aspen, poplar, and canoe birch on the ridges.

From the southern end of the lake, by a large brook entering the southeasterly bay, a route to be referred to again, leads to the Attawapiskat river.

For the next twelve miles, between Nibinamik and Wapikopa Iole-, the river flows with a fairly stiff current, increasing to rapids at three places, and descends in all about thirty-fire feet. No ledges are seen along the shores, the orer-mantle of drift, rising in places to form ridges ninety feet in height, quite covering the underlying rocks.

Wapikopa lake has a length northeasterly of thirteen miles, with a long irregular bay running to the north for fourteen miles, where it receives the waters of the river of the same name, a quiet flowing stream thirty yards wide, two to six feet deep, and with a sluggish current of about one mile an hour.

Yang exposures of biotite gneiss occur about the lake-shores, the foliation well marked, and dipping at angles of from forty degrees to horizontal. A coarser grey gneiss cuts these stratiform beds. and ancloses in places angular blocks of the finer black gneiss in such numbers as to ennstitute a breccia. 
A newer reddish granite, with porphyritic crystals of red feldspar, occurs in heavy ledges near the west end.

Green forest from thirty to one hundred years old clothes the shores of the lake on every side.

From Wapikopa lake downwards to Weibikwei lake, a distance of thirty-eight miles, the river follows a most irregular course, and really constitutes a succession of lakes, with intervening rapids, the total deseent being about eighty feet.

The lake-like expansions are remarkable for the way in which the long narrow bays, running off from them, conform to the direction of glaciation. This is cansed by the recurrence of parallel ridges of glacial drift, with a directiou about N. $30^{\circ} \mathrm{E}$., the valleys between them forming the basins of the lakes.

A number of small rapids occur where the river breaks through the drift ridges, and for ten miles immediately above the outflow of the channel coming in below Weibikwei lake the current is very swift, and heavy rapids occur, some of them over ledges of biotite gneiss.

These rocks, the only exposures seen, are fine, banded black and grey biotite gneisses, dipping at various angles but preserving a general northeasterly trend. They are invaded by irregular masses of a coarser white gneiss, that sometimes occurs as bands conforming to their foliation, but often cuts them in the form of apophyses, and surrounds and encloses angular blocks and masses.

Midway, at a point above Kanuchuan lake, where the river divides into a number of channels, a small brook flowing in from the south is the starting point for a route across to Lansdowne lake, and nine miles above Weibikwei lake a channel leads off to the north, rejoining the main river just below that lake.

The southern channel of the river flows into the northwesterly bay of Weibikwei lake and discharges from its extreme northern end.

Weibikwei lake has an extreme length of seventeen miles, and is seven miles wide. Two rivers of considerable volume flow into its southern end, the Michikenopik (stone fish-trap)-known on the old maps as the Fishbasket river-and the Wapitotem, up which the principal canoe route to the south leads.

The lake, though of considerable area, nowhere shows any wide expanse of open wider. consisting of a series of long, narros 
channels, lying about north and sonth, between parallel low islands of sand, gravel and boulders, with a substratum of till reaching about the level of the top of the water. The passages are not generally more than half a mile in wilth, and only thirty feet in depth. The land about the lake is low, and has been ahmost entirely denuded of trees by recurring fires, excepting in a few loealities where Banksian pine, tamarack, and spruce of fair size remain to show the charaeter of the original forest. Sturgeon, whitefish, pike, and doré of good size are plentiful in the lake, and the Indians say that brook trout are not uncommon, but that lake trout do not oceur. The only ledges about the shores are biotite gneisses that form low points near the southern end of the lake.

The river discharges from the extreme northern bay of the lake by a short rapid, with a fall of three or four feet. Just below the rapid, at the head of a long bay that extends for several miles to the west, the ehannel which leaves the river ten miles above rejoins. This is probably really the main ehannel of the river. Below the junction the river flows for the first eight miles of its eourse orer horizontally foliated ledges of banded, biotite gneiss, that cause an almost continuons succession of rapids with swift water between, down to the point of outflow of the Winiskisis, a channel that flows off to the northeast, to become remited to the main river seventy miles below. At low water no water flows over the bar at the entrance to this channel, though there is, at all stages of the water, a river of considerable size coming in at the junction, due, the Indians say, not to any single large stream, but to a great number of smaller tributaries draining the country between this strean and the heads of the Ekwan and Black-fence branch of the Attawapiskat ricers. Thirteen miles below the head of the island thus formed, another branch ehannel, ealled the Tabasokwia, splits off to the west and flows around an island about twenty-three miles long. For fortyfire miles below the lake, or to the upper edge of the till-corered area, the river is an almost continuous rapid, the descent being probably as much as seven feet to the mile. At two points only do these rapids beeome caseades, both situated near the bottom of the rery rapid seetion. At the Tashka rapid the rertical fall is not great, but at the Boskineig or Smoky fall there is a rertical piteh of about fifteen feet. The portage past the first of these rapids mounts orer a low ridge of boulder elay, but eut banks, showing a section through the till, are first seen just alove the Boskineig fall, where the river 
has cut down through twenty feet of an upper buff-coloured elay, and six feet of an underlying, exceedingly tough blue elay holding many well striated boulders.

Below the fall the eut banks of boulker clay become higher, and a few inches at the summit are scen to be stratified. Four miles below, in the thin layer of stratified beds at the top, the first fossil shells, Saxicava rugosa, were noted, proving these beds to be of post-glaeial, marine origin. The height above the sea is estimated to be about 350 feet. The banks, along this part of the river's course, are low, rising gradually from almost water level to heights of not more than fifty feet above it.

Frequent exposures of biotite gneiss, generally nearly horizontal, but much disturbed by intrusions of a coarser white gneiss, and by veins and apophyses of pegmatite, occur all along the river. They are low, rounded, well-glaciated ledges, slowing well marked striation in a general direetion varying from south to southwest, but showing oeeasional striæ, that are probably later, having a direction about southeast. Down to this point, and for a few miles beyond, the old forest has bcen destroyed by the same fire that swept the shores of Weibikwei lake, and its place taken by a second growth about thirty years old.

Oceasional low bosses of biotite granite-gneiss are exposed along the shores for sixteen miles below Boskineig fall. A horizontal or gently undulating foliation is well developed, though the regular uniformity of their attitude is marred by irequent invading masses of coarse white gneiss and pegmatite. These exposures are the last that outerop along the river until the outer rim of the limestones of the Hudson Bay basin is reaehed, 140 miles below. Though the bottom of the trough gradually beeomes lower in reference to the surface of the till as the river is deseended, at no plaee in this distanee has degradation bcen arried far enough to expose the underlying roeks, the great number of boulders derived from the wearing away of the till probably beeoming an increasingly important factor in retarding the wearing action of the current.

Below the last exposure of gneiss the old forest still clothes the banks, the brulé above referred to extending only to that distance. The banks of the river preserve, all along the part of its course lying within the till-eovered area, a very uniform charaeter. The shores between low and high water mark gradually slope up from the 
water's edge, and are often paved with boulders, and marked at the upper edge by a belt of low bushes and grasses. From high water mark the bank of boulder clay rises in an alwost sheer wall, bare and raw looking, like the side of a recent railway cutting or canal; the lower till often rough with the great number of projecting boulders, but the upper smooth faced like a pure clas. Capping the upper clay is a rery unequally distributed layer of marine clay, in places reaching a thickness of ten feet, but orer long distances entirely wanting.

The impervious character of the till, together with its nearly flat or gently undulating surface, gires to the country a muskeg-like character, eren though it lies eighty feet or more above the bet of the river. Along the immediate banks, and for perhaps a chain or two back, there is a narrow belt of trees of fair size, and back of that stretches away a great level, plateau-like country, practically without drainage, and consequently moss-corered to a great depth, supporting a stunted and deformed growth of black spruce and tamarack. There is no river valley, the trench cut in the boulder clay being but little wider than the actual bed of the stream. The comparatively stable character of the till walls is indicated by this belt of larger growth, as, were the disintegration proceeding at all rapidly, the ordinary condition of tree growth would prevail quite to the edge of the trough.

At sixty-eight and serenty-seven miles, respectively, below Weibikwei lake, the Tabasokwia and Winiskisis channels rejoin the parent stream, the latter now of considerable volume. At a lake-like expansion studded with islands, situated seren miles below the inflow of the Little Winisk, the first tributaries of importance join the river, the Asheweig flowing from the southwest, and the Atikameg from the southeast. The former of these, which is slightly the larger, is the West Winisk of the old maps, and the stream referred to on a former page as flowing out from the main river at Misamikwash lake 224 miles above. At its outlet it is a quiet flowing stream, with a good current, a chain or more in width, and having an average depth of about four feet. A short distance below this point white birches and balsam spruces are seen for the last time on the banks, and thence to the sea the forest growth, quite to the edge of the river trough, is composed entirely of black spruce and tamarack. The islands, and here and there a projecting point, however, continue to show groves of white spruce, balsam poplar, and aspen. 
After a course almost directly north, with slight curves to the east and west, for 126 miles, the river by a sharp turn suddenly changes its direction to a little south of east, and keeps that trend for serenty miles.

Looking down the valley from a point a few miles above the elbow, the land to the north, beyond the turn, is seen to be elevated a little above the general level, the line of higher ground probably representing the northern edge of the Silurian basin. The abrupt turn made by the river, and its long detour to the east before resuming its normal northerly direction, may probably also be attributable to the presence of the barrier cffered by the rim of the limestone area.

Two tributaries, the Banipatan and the Pikwakwud, join the main river near the elbow. Both head near the Fawn branch of the Severn river, and by the last named there is a canoe route to the Severn. The Winino brook comes in from the north about half-way down the easterly stretch, and nine miles farther on an island six miles in length, known to the Indians as Atikminis, or Caribou island, divides the river into two channels of nearly equal volume. The almost sheer walls of boulde: clay, with their intermittent and irregular capping of marine clay, continue to rise in reference to the river bed, until at a point fifiy miles above the mouth they attain a height of eighty-five feet above the water level, with a bed of but slightly beached and not at all decayed sphagnum moss on top. The marine clays with their contained fossils, a list of which is published elsewhere in this report, immediately underlie the moss. The limestones and dolomites of the Hudson Bay basin first outcrop at a distance of forty-two miles from the bay, measuring along the river. They are flat-lying, slightly magnesian, flaggy limestones, forming the bed of the river, but not appearing above the water. Within a very few miles, however, the slope of the river carries it below the surface of the limestones so that they form low walls, gradually increasing in height in reference to the suriace of the water until, four miles below, the river flows through a gorge cut to a depth of thirty feet in the limestones and dolomites. This is probably a part of an old pre-glacial channel, as from here on down towards the sea the limestone walls, capped by boulder clay, alternate with banks that show till only down to high water mark. The surface of the country, extending back from the sides of the river-trough, has the 
sanc platcallike character stretching away as far as the eye can ce. as in ahmost level, moss-covered plain, with only a sparse growth of stunted trees.

The limestones show gentle undulations, but are, broadly speaking, nearly that, with a slope northerly corresponding elosely with the descent of the river. A small collection of fossils, determined by Dr. Whiteaves, is referred to more at length on another page. 'They serve to satisfactorily fix the position of these berls as Silurian, and of about the age of the Niagara.

It a projecting point on the southeast bank, twenty-six miles from the noutl, an entirely different set of rocks is brought to the surface, in the form of a double anticlinal fold, whose axis strikes south $70^{\circ}$ east. These consist of banded green and black slates and calcareous quartzites, the whole very hard and baked looking. No actual eontact with the overlying dolomites or limestones is seen, so that it is not possible to say with certainty whether or not the two sets are conformable. It seems very probable, however, that the upper beds, that gradually merge upwards from a caleareons quartzite into a highly siliceous lirestone, underlie conformably the lowest stratum of limestone. No fossils were found in these beds. The ribboned character of the slates, their bright coloration, and the occurrence in them of streams of more highly calcareous pebblelike pieces that are very suggestive of broken limestone bands, give to them a most striking appearance, and would make their recognition, if exposed at any other place on the river, almost a certainty. It was considered at the time that these might represent a part of the Nastapoka series noted by Mr. Dowling about thirty miles to the east, on Sutton Mill lake. There does not seem, however, to be a sufficient similarity between these beds and those deseribed by Mr. Dowling to warrant this correlation. Below this point, and down nearly to the mouth of the river, the limestones and dolomites, for the most part a repetition of the same beds lying in low undulations, ale almosi continuously exposed, forming low eliffs, overlain by a thick mantle of boulder clay. The river, along this part of its course, $i$ abont thirty chans wide, with many expansions three-fuarters of a mile or more in width, and dotted with islands.

The Mattawa, a river of considerable volume, by which there is an Indian canoe ronte to the Ekwan river, comes in from the east twenty-four miles from the month, and ten miles farther down the Mishamattawa, or Big Mattawa, flows in from the west. This stream 
is used by the Indians as an inland canoe ronte to the mouth of the Severn, which is reached by ascending the stream almost to its head and crossing thenee to the Shagamu, which flows into the west shore of Hudson bay about a day and a half's journey below the Severn.

For the last twenty-five miles of its course before reaching the shores of the bay, the river has an average width of about threequarters of a mile, but expands to over a mile at many places. An almost continuous line of islands divides it into a number of chamels all along this part of its eourse. For the last twelve miles above the sea these islands are generally low, and clothed only with grasses and low bushes, but varied by occasional, more elevated ones that support groves of balsam poplar of good size. Above this the islanls are mostly masses of till that have resisted the wear of the current; they are higher and generally well wooded with large white spruce, that attain diameters as great as two feet, and are tall and straight.

The current is swift for the whole distance from Weibikwei lake to the mouth, a distance of 240 miles, though across the boulder clay area, and through the limestones, the descent is comparatively uniform. Though there is water enough all along for tracking canoes, a chamel suitable for larger boats could only be found by following a very tortuous course, and by frequently erossing from side to side, where the flat limestone ledges, approaching the surface, form almost continuous barriers across the current, with perhaps only one break where the water has any considerable depth.

This even slope is characteristic of all the rivers flowing from the great central Arelixan plateau downwards to the west coasts of Hudson and James bavs, after they have passed the more elevated Archæan country and reached the gently sloping till-covered area. The Albany, the Attawapiskat, and the Severn rivers are other examples of this. The absence of any valley might be interpreted to mean that the river, in its present form, is rery recent. It must be borne in mind, however, that evidence of a considerable age is afforded by the gorge in the limestones where the river flows in a channel cut down at least forty feet into the flat-lying strata, and all along in its passage through the sedimentary belt its pre-glacial age is indicated by the cliffs of limestone that appear alternately on the one side and on the other, with bonlder clay forming the banks in the interrening spaces, constituting what is practically a broad. slaallow, partly till-filled gorge all the way.

toit-3 
It seems evident then that through the boulder clay area, until the limestones are reached, the present channel does not necessarily represent an older valley, but that below, through the limestones, the river has resumed possession of an older, pre-glacial ehannel.

Approaching the mouth the banks beeome lower, and for the last few miles are not generally more than about fifteen feet high, and are composed of stratified clays and sands. Bordering each side of the river at the estuary, and extending back from the shore of the bay to form a belt from two to five miles in width, a treeless tract four or five feet above ordinary high tides extends away to the east and north, and is probably continuous, almost without interruption, up and down the west shore of the bay. It is a comparatively level plain, intersected, however, by many channels that are filled at high tide, with a gravelly and sandy surface sparsely eovered by clumps of grass and brightened by many speeies of sub-arctic flowering plants. The river has an easterly direction just at its mouth, and the south shore consequently becomes, without change of direction, the coast of the bay; and it is only by the turning away to the north of the opposite shore that the actual mouth of the river can be fxed. At this point the estuary has a width of about three miles. It is generally shallow, large boulders showing above the surface even at high tide, while at low tide bars of sand, gravel and boulders are exposed. The ordinary rise and fall of the tide is only about six feet, but this is sufficient, so flat is the bottom of the bay in this neighbourhood, to expose at low tide wide sand flats extending far out from the actual shore rine and dotted with large blocks and boulders, mainly of limestone, that in places are heaped together to form points and low ridges that remain uncovered even at high tide.

The shallow character of the bay was further evideneed, when the mouth was visited in August, 1903, by the barrier of pack ice that formed a continuous line across the estuary, about five miles off shore. The small sailing ressel used by the IIndson's Bay Company for the transport of supplies from the post at the mouth of the Severn river to the Winisk river is forced, by the shallow water off the mouth, to make a long eircuit, following the ehannel of the river from far out in the bay.

The length of the Winisk actually traversed, from Misamikwash lake to the mouth, is 365 miles. As it is a riv $\mathbf{r}$ of consicerable rolume at the upper point reached, it may be confidently stated that its total length is well over 400 miles. 


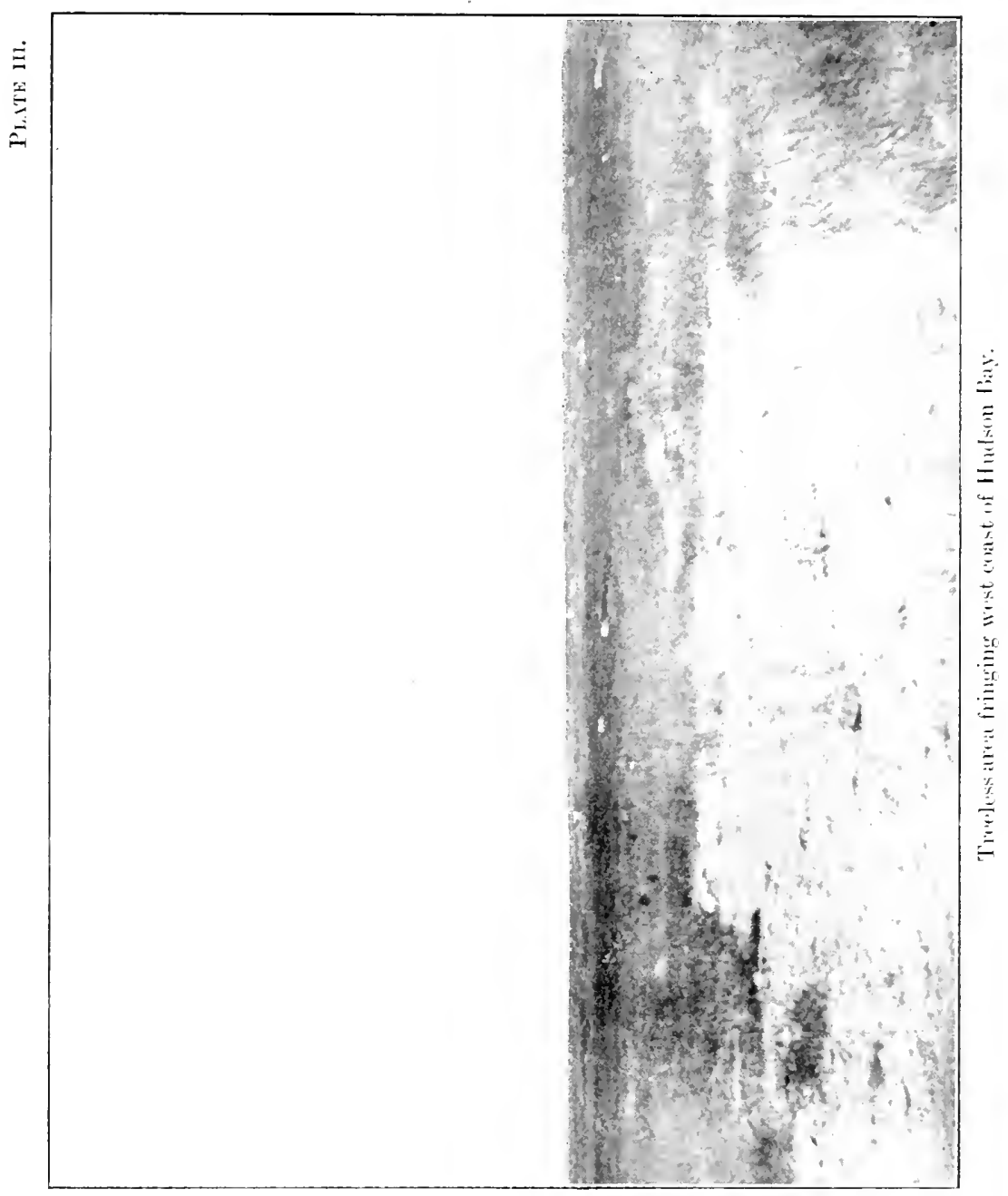

$4074-$ p. 34 

Its volume was estimated to be about 25,000 cubic feet per second in midsummer, at a point twenty-five miles above the bay.

To avoid the difficult narigation of the west coast of Hudson bay, the Indians have well-known routes both east and west from the Winisk, the western leading to the Severn river by a stream called the Mishamattawa, which enters the Winisk six miles from the mouth. From near the headwaters of this stream the Shagamu river is reached by a portage route, and that stream is descended to the coast, which is reached at a point about a day and a half's journey from the mouth of the Serern river. The eastern route leares the Winisk eleven miles from the mouth by its tributary the Shamattara. This stream is ascended to a large lake on its course, and one of the tributaries entering the lake is utilized to reach a stream flowing into the Ekwan river by which the western side of James bar is reached. By this route the hazardous journey for canoes along the exposed west coast and around the point of Cape Henrietta Maria is avoided.

\section{The Attawapiskat River.}

The Attawapiskat river was examined to the main forks twenty miles above Lansdowne lake, and its southern branch, the Kanuchuan, for 135 miles farther, where it overlaps the foot of Lake St. Joseph at a distance of about fifteen miles to the north.

A micrometer survey was made of the greater part of this distance, connecting at one end with Lake St. Joseph and at the other with Fort Hope post on Eabemet lake.

The Attawapiskat watershed was first reached at Wimbobika and Kapichegima lakes, lying about twelve miles to the northwest of the northeasterly end of Lake St. Joseph. The upward continuation of the river is represented by two large brooks flowing in from the west, and one, known as the Rice-stalk river, from the north. The latter affords a canoc route to Cat lake. This has been traversed by Mr. Jabez Willians, of the Hudson's Bay Comnany, who reports that biotite gneisses only are exposed along the route.

These lakes, both long, narrow and trending about east, parallel to the prevailing strike of the gneisses in that ricinity, are separated by a low ridge of chloritic, feldspathic hornblende-schists, that occur in a belt, at this point not more than three-quarters of a mile wide. The westerly extension of this belt was not traced, but it prob-

$40 \div-31$ 
ably does not reach the shores of Lake St. Joseph, as it appears to be tapering in this direction. Easterly it was traced pretty continuonsly, as the stream valley has been excavated in these rocks practically all down its course.

The outlets of these two lakes unite a few miles below to form the small river known to the Indians as the Kawinogans, or NoPikerel river. For twenty-five miles below the junction the river has a width of only from one to two ehains, and is swift flowing and broken by numerous rapids. At frequent intervals exposures of chloritie and feldspathie sehists outerop, striking both to the north and south of east, or parallel to the general course of the river valley:

Ascociated with the sehists are more or less schistose diorites, and massive pyritous quartz diorites. At the edge of the belt is a strip of hornblende granite gneiss similar to the biotite gneiss, exeepting that in it the biotite has been replaced by hornblende.

The trend of the belt of basic rocks would earry it to the south of the long narrow lake called by the Indians Kagabades-dawaga. Excursions inland from the south shore of this lake revealed no outcrops, and as no further exposures of these rocks were seen on the river, the belt probably terminates in this direction not far east of the hear of the lake. Along the lake shores ledges of roek were seen at only one point, where obseurely foliated biotite gneisses are eut by a later red granite of mediun grain.

Stratified fine white quartz sand, underlain by blue clay and overlain by gravel, forms banks from ten to thirty feet in height all along both sides of the lake.

Among the peach pebbles, which oceur in great variety, are included dolomites and fossiliferous limestones, as well as many large semi-angular blocks, indieating that the underlying clay is probably a till.

Where the banks are low, and fresh sections are afforded by the work of the waves, a laver of peat from two to three feet thick overlies the clay. From the south shore of the lake a rolling, sandyeovered slope, the surface coated with white moss, and supporting an open growth of jackpine, white bireh, and spruce, gradually rises to the summit of a ridge two hundred feet or more above the river. Along the side of the ridge, which is entirely of drift material, are numerons cirque-like depressions sixty to ninety feet deep, with 
steeply-sloping sides, and in a few cases holding up small ponds of water: The opposite or southeast side of the ridge falls away abruptly, at as steep an angle as the sand will assume, to another rolling sandy plateau that extends for miles to the southeast.

The Otosk or Elbow river, probably the longest of the rarious branches of the Attawapiskat, as it heads near the northeast end of Cat lake, flows into the lake from the northwest, about half-way down its northern side.

Eleven miles below, after flowing in an easterly direction past a number of rapids, with oecasionsl outcrops of biotite granite-gneiss, the river expands to form Iiakawizida lake, a shallow body of water ten miles in length and a mile wide. The same rolling, sandy plain, with extensive tracts of muskeg where it approaches the south shore, surrounds the lake. Beyond the muskeg area, which extends for two miles or more back from the lake, the land gradually rises to about a hundred feet, where glacially planed surfaces of gueiss, coarse and obscurely foliated, outcrop through the drift covering. Beyond, the sandy flat gradually gains in elevation sonthrvards for five or six miles, and then rises sharply to form a ridge of gravel and boulders 300 feet above the lake, only a few feet wide at the summit, and falling away abruptly to the south and east to a well-wooded raller. An open forest of banksian pine covers the whole of the sand plateau.

From the summit of the ridge described others are seen, apparently of similar character and with the same general east and west trend. Twenty-nine miles farther down the river, which still keeps an easterly direction, Ozhiski or Mud lake oceupies a shallow trough, twenty-one miles long and a little over two miles wide at the broadest part. Shelving ledges of biotite granite-gneiss, lying nearly horizontal, or gently mdulating, ocenr at many points along the shores. The country traversed by the river for the last fifty miles above the lake is characterized by rery heavy deposits of drift, mostly stratified and often from fifty to sixty feet in thickness. Where sections are exposed along the river or lake shores, by the wear of the water, the greatest thickness is secn to be occupied by very fine, white. quartz sand and siliceous elay, underlain by a tough blue clay, in fine laminations, and overlain by irregularly distributed deposits of coarse sand and gravel. Underneath the whole, and resting immediately upon the hed-rock, are deposits of tili of mequal thickness, that at no place are exposed in section. 
Occasional Jenticular layer's of indurated calcareous material, one to two inches in thickness, holding approximately 59 per cent of calcium carbonate, oecur in the siliceous clays. Two specimens of the clay were cxamined by Dr. Hoffinann, one from the neighbourhood of Ozhiski lake and one from higher up to Kanuchuan river. Dittering only in the proportion of their lime content, they are described as slightly ferruginous, feebly plastic, readily fusible clays, holding a large quantity of siliceous grit and containing from $2^{-7}$ to 30 per cent of calcium carbonate. In combination with the vegetable monld of the surface these clays should form a soil very suitable for general agriculture, though they are evidently not of value for industrial use as clays.

Flowing out from the north side of Ozhiski lake the river continues northerly for fifteen miles, with many heavy rapids and a bigh arerage rate of flow, to an elbow, where it changes the direction of its course sharply to the east.

Ledges of well foliated, banded, biotite granite-gneiss protrude through the drift mantle at frequent intervals along the river valley, generally lying at low angles, but in places very much contorted and crumpled. The prevailing strike is about northeast. The Pineimuta, or north branch of the Attawapiskat, comes in from the west just at the elbow. Though somewhat smaller than the south branch, this is a river of considerable volume. For the first few miles above the forks it is broad and smooth-flowing, with banks of clay and sand, and is then broken by a ligh fall, above which it receives a large tributary that chains Totogan lake, lying a short distance to the north of the south branch, above Ozhiski lake. Above this the Indians say that the river takes a very long bend to the north and then southwest, and heads near the sources of the Pipestone branch of the Winisk. From the elbow the river, now nearly doubled in volume, flows easterly for twenty miles into the long southwesterly bay of Lansdowne lake. It is a succelssion of lake expansions, with comnecting rapids, which, tlough they are rough, can all be run by loaded canoes. Kabania, eleven miles long and generally quite narrow, is the largest of these lakes. The land about the lake is low and drift covered, nearly horizontal, but contorted ledges of banded, biotite gneiss, with glaciated surfaces, showing at intervals.

Lansdowne lake, and the lower Attawipiskat riter to James bay, have been described by Dr. Bell in his report published in 1887. 


\section{Routes between the Attawapiskat and Winisk Rivers.}

The tract of country lying between the Attawapiskat and Winisk rivers was crossed by three canoe routes, two starting from Lansdowne lake and one from the Attawapiskat river, ten miles above the lake, and striking the Winisk at Weibikwei lake, between Wapikopa lake and Fanuchuan lake, and at Nibinamik lake respectively. The first-named route leaves the extreme northeasterly bay of the lake, and reaches the height-of-land by way of a small boulder-strewn brook, flowing through low land with occasional gravel and boulder ridges of moderate height. After crossing the divide the route follows the course of the Wapitotem river, through numerous lakes down to the south bay of Weibikwei lake. For the whole distance the country is charicterized by drift ridges, rising from seventy to one hundred feet above the general level, with areas of muskeg and low, sandcovered flats occupying the intervening valleys. For the first. thirteen miles north of Lansdowne lake no exposures of rock in situ are seen, the drift cover hiding completely the underlying rock. A low ridge of slightly schistose, hard, chloritic diorite, specked with iron-pyrites and striking east and west, is the first outcrop observed. The width of the band of which it forms a part cannot be determined even approximately, as to the north the first rock outcropping through the drift occurs on Mistassin lake six miles farther on, and to the soutl the nearest is on Lansdowne lake nineteen miles away. These, in both cases, are biotite gneisses, the last being the first of a series of exposures that occur at intervals all the way down the stream to Weibikwei lake. The trend is in a general way about east and west, though satisfactory strikes are seldom seen owing to the contorted character of the strata, due principally to pegmatite invasions where the foliation is plain, or to obscure foliation.

The prevailing type of rock is a hard, reddish, banded, biotite gneiss, lying nearly horizontal, stratiform in appearance, and cut by irregular masse and veins of coarse white pegmatite. The distance across by this route is sixty-five miles, and for the whole distance the country, excepting a few low, muskeg areas, has been repeatedly swept by forest fires, so that many of the ridges show surfaces of bare boulders and gravel, and other a second growth of banksian piue, white birch, aspen poplar, spruce, and tamarack. In the muskeg: tracts only spruce and tamarack grow, and the trunks do not attain a size to be of industrial value. 
Low, rounded bosses of biotite gneiss, varying from very coarso to quite fine and containing a large proportion of biotite, are exposed at intervals to leyond Sagamimnis lake. The prevailing strike is a little west of south. At the northeast end of a long portage between two small lakes, lying about mirlway in the series, one of these low bosses is composed of interbanded fine quartzose gneiss and hornblende schist, the fine gneiss resembling a finely mieaceous, schistose quartzite, and the whole striking in conformity to the foliation of the gneisses that are exposed at no great distance on either side. The strata are much shattered and seamed with quartz veins containing iron sulphide. This is probably an offshoot from, or continuation of the belt to be next referred to.

Crossing another divide the route continues to Nibinamik lake, through numerous small lakes occurring along the course of a small tributary flowing northwesterly into the most southerly bay of the lake. The stream valley follows the trend of a belt of basic rocks from one to two miles wide, and traced in a compound curve northerly, northwesterly, and northeasterly for twelve miles.

Chloritie and hormblende sehists, assoeiated with highly altered and sheared quartz diorites, are the prevailing rocks at the lower end of the belt. Farther north on the band more massive, hard diorites, and coarse diabases altered in places to obscurely schistose chloritic rocks, oceur with the schists, all striking parallel to the longitudinal axis of the belt. At intervals for a distance of more than two miles massive ledges of hypersthene gabbro, similar to the Sudbury niekelbearing irruptive, whose relations to the other rock masses were not clearly seen, but which oecur at or near the western edge of the belt, are associated with a massive hard, dark-green diabase.

The belt, striking northeasterly, passes just to the east of Nibinamik lake and should eross the Winisk river a few miles belor the foot of the lake. Owing to the continuous drift corering no exposures of rock in situ were seen along this section of the river.

The most westerly route traversed ascends the Pusabiwan river, a tributary entering the Attawapiskat from the north at the foot of Kabania lake. For the first few miles to the north of the river no exposures of hard roek are seen, the surface consisting of rolling hills of sand and clay. Beyond, though the comntry is for the most part drift eovered, numerous outerops of bictite gneiss, flat-lying or gently undulating, are seen along the river and lake shores to the 
height-of-land separating these waters from those of the Michikenopik brook flowing into the south end of Weibikwei lake. Northerly from here the route follows a series of small lakes lying near the heads of streams flowing northeasterly into the Winisk, for a distance of twenty miles. Large areas of muskeg, and low sandy flats, occupy the greater part of the area traversed, diversitied only br sand, gravel, and boulder ridges that nowhere rise to elevations of more than eighty or ninety feet above the general level.

The second route, leaving the northwesterly bay of Lansdowne lake by a portage orer a low ridge of unassorted sand, gravel and boulders, ascends a small brook through a series of lakes situated along its course, for a distance of eight miles, to a divide between the Attawapiskat and Winisk watersheds.

Occasional outcrops of biotite granite-gneiss lying at low angles are seen to within about three miles of the height-of-land, beyond which, after a short interval completely drift corered, exposures of ruassive diorite, and hornblendic and chloritic schist are seen. for il distance of about four miles. These, without doubt, are extensions westerly of the belt of these rocks, deseribed in connexion with the first route as crosing a short distance to the north of Attawapiskat lake.

Continuing nortl the route follows a small stream downwarls to Mameigwess lake, a body of water covering a considerable arca, but of very irregular outline and broken by many islands and longr points.

Biotite gneisses are the only outerops that sliow through the drift leposits covering the greater part of the surface. From the foot of Mameigwess the route follows a number of small lakes to in small stream, which it descends to a southerly channel of the Winisk river fifteen miles below Wapikopa lake. Biotite gusisses only are exposed all the way through to the main river.

\section{Routes between the Winisk River and Trout Lake.}

Two eanoe routes between the upper waters of the Winisk and Severn rivers were explored. The mast westerly of these leaves the Winisk at Misamikwash lake, and the other at the first northerly expansion above Nibinamik lake.

Descending a small outlet that flows through a boulder-choked channel from the northeasterly hay of the lake, the first-mentioned 
route follows this strean-that by the addition of tributary brooks gradually becomes a river of considerable volume-northwards for Iity miles to a small lake known on the old maps as Sturgeon lake. For this distance the chamnel has a steep gradient, and the route is impeded by frequent rapids. Several lakes occur along its course, the largest, ten miles long and a mile and a balf wide, lying not more than two miles to the north of Misamikwash lake. The country is generally low and drift covered, with only occasional exposures, all, excepting a few isolated outcrops of hornblende schist near Kingfisher lake, of biotite granite-gneiss.

From Sturgeon lake, a small tributary from the west, draining a chain of small lakes with connecting rapids, is ascended for thirteen miles to the divide. The rapids are many of them rough, and all are shallow, so that the stream is navigable with difficulty even by light eanoes. The obstructions are caused by erratics that have been washed out from boulder and gravel ridges that cross the stream at frequent intervals. From the divide, Nemeigusabins lake and its outlet, a small stream with many rapids, lead to the southeast corner of Trout lake. The shores of Trout lake in the ricinity of the mouth of Nemeigusabins brook and for eight miles or more westerly are generally low and boulder strewn, the land back from the lake rising gradually over morainic ridges of gravel and sand. Oceasional outcrops of banded biotite gneiss, well foliated and lying horizontally, or gently undulating, occur here and there in low, rounded exposures near the lake shores. Most of the country seen near the lake has been burnt over, and the present forest, over all but rery wet muskeg areas, is a second growth of small size.

Aroiding the shalluw streams between Sturgeon and Trout lakes an alternative route follows an almost direct line through nine small lakes or ponds, connected by ten portages aggregating a little over five miles and a half in length.

The section traversed is a nearly flat, sand-corered plain, with oceasional low, drift ridges and extensive areas of muskeg.

The second route referred to follows the west branch of the Winisk down stream from Sturgeon lake for thirty-three miles in an easterly and then southerly direction, to a small lake where the rirer changes its course to a northerly direction.

The country traversed by the river is similar to that erossed by the main Winisk in one of its most striking features, namely, the 
cocurrence of parallel glacial rirlges that deflect the course of the channel and of the lakes to a series of zig-zags conforming to the trend of the glaciation. The country is, however, more level and not so well drained as that bordering the main river; the proportion of swampy land is larger and the forest growth consists largely of black spruce and tamarack.

Leaving the west branch a short divide is crossed, and a stream. flowing southwesterly, probably into one of the northern bays of Wumummin lake, is ascended in a southeasterly direction through an ahmost continuous chain of lakes, with short rapid intervals of river joining them, for twenty-one miles, to a minor divide separating the headwaters of this stream from another small river flowing southeasterly to the Winisk above Nibinamik lake, a distance of thirty-six miles. The country is of the same general character, and the lakes, and to some extent the river chamnel, show the same parallelism to the glaciation, due as before to the ridges of transported boulders and gravel.

The covering of drift material is so universal, and the relief so small, that the underlying rocks cin seldom be determined. Wherever outcrops occur they are biotite granite gneisses, so that if the Wumummin Lake belt of conglomerates and schists extends to this distance casterly, as would seem probable, they are entirely concealed bre surface deposits, and cross the route at one of the long intervals without exposures.

\section{Route between the Albany and Attawapiskat Rivers.}

The route principally used between the Albany and Attawapiskat rivers leaves the former river at Eabemet lake and reaches the latter at Lansdowne lake, traversing a distance of seventy-five miles. The first thirty miles from the Nlbany through Eabemet. Rib, and Kenozhe lakes to Machawaian lake wa- traversed by Dr. Bell in 1886, and has been described by him in his report on 'An Fxploration of Portions of the Attawapiskat and Albany Rivers,' published by the Geological Survey in 1887. The belt of diorites and felsitic, chloritic, and hornblende schists that crosses the Albany river at Petawanga lake crosses this route just north of Eabemet lake, in a hand about nine miles wide, running $\mathrm{N}$. $70^{\circ}$ E. For the balance of the distance to Lansdowne lake, wherever outcrops are seen they are of biotite 
granite-gneis of medium grain, striking about east and west, and banded fine black biotite gneiss eut by a course gneios that encloses blocks of the finer.

From the northwesterly hay of Machawaian lake the divide between the Attawapiskat and Albany waters is crossed, at a distance of two miles to the north of the lake, by a portage seventy-four chains in length, traversing a muskeg with occasional ridges of transported gravel and boulders.

Manitush lake, two miles long, lying at the north end of the portage, discharges northerly by a small stream, barely navigable by canoes, into Marten Drinking river, which the ronte follows through Hail lake to Wintawanan lake, from which there is a route westerly through an intervening small lake, to the south branch of the Attawapiskat river at Ozhiski lake. The Marten Drinking river, rather shallow and with a number of rapids along its course, is nevertheless navigable by eanoes down to its mouth at one of the southerly bays of Lansdowne lake. The comntry between the two rivers in the neighbourhood of the route is a high, rolling plateau, rising, midway, about a thousand feet above the sea, or a hundred feet above the Albany at the point of departure. Large areas of muskeg abound, from which rise low, rounded bosses of gneiss, and ridges of sand, gravel, and bonlders.

To the west of Maehawaian lake the country is much more broken and rises to higher elevations. This more elerated region extends in a belt westerly past Trout and Cedar lakes, and without doubt continues still farther west, forming the height-of-land between the Allany and the south branch of the Attawapiskat. This country is referred to in the deseription of the route down the Kanuehuan river on a merions page, where the hills are stated to be compased of transporterl material to their summits.

\section{Cultivation of the Land.}

In the matter of the actual eultivation of these northern areas we have little to go upon. At the Hudson's Bay Company's posts at Fort Hope and Osmaburgh potatoes have been grown, and small gardens maintained from the time of the establishment of the posts. and little diffieulty has been experienced in maturing the common garden vegetables of Ontario, thongh oceasionally the frosts of late summer have cut off all but the hardier kinds. As the posts were 
located with a view to their farourable situation for the purposes of the fur trade with the Indians, neither one is situated on ground well suited for cultivation, and much better results might reasonably be expected were trials made on more favourably situated tracts.

An Indian cultivating a small garden plot at the head of the Pineimuta braneh of the Attawapiskat river sueceeds in raising good erops of potatoes and turnips.

Fish.

Whitefish and sturgeon are the best food fishes, and occur in most of the lakes. Both are taken in nets, and the latter al-o by spearing from seaffolds built out over rapids in the rivers. Doré and pike are also generally distributed over the whole area, and form an important source of food supply, though the sucker among the fishes, like the rabbit among the mammals, holds the most important place, as it can be caught everywhere, not only in the larger lakes but also in the smaller ponds and streams.

Brook trout were actually eanght only in the Winisk river near its mouth, and in the streams rumning into the Albany river, but were seen in the rapids below Weibikwei; the Indians assert that they occur also in the lake itself.

Lake trout were eaught in large numbers in Tront lake at the head of the Severn river, but are not found in either the Winisk or Attawapiskat waters.

\section{Wild Animals.}

The moose (Alces americanus) has been found as far north as the southern shore of Weibikwei lake, in $N$. lat. $52^{\circ} 50^{\prime}$, though tracks were actually seen during our exploration only as far north as the Attawapiskat river. Even here it is not nearly so plentiful as farther south in the belt of country lying near the Canadian Pacifie railway and extending for about 150 miles north of it.

Caribou (Rangifer caribou) range all over the district.

No red deer are found anywhere throughout the region.

The fur-bearing animals, though not so plentiful as they once were, are still fairly abundant throughout the district; the otter and the bearer from long-contimued trapping are less numerons perhips, than any other species. 
Bears (Uisus americanus) seem to be able to hold their own pretty well, and are still taken in good numbers. There is probably but one species of the common black bear, though the Indians and traders differentiate from this the brom bear, which they claim differs from the black, not only in colour and size, but also in disposition and habits.

Wolves (Canis lupus), though scarce, are not unknown.

Foxes (Vulpes vulgaris), including the red, silver, black and cross varieties, are numerous, though they vary in numbers with the periodic increase and decrease in the numbers of the hares.

Iynxes (Lynx canadensis) are fairly plentiful.

Otters (Lutra canadensis), and Pine martens (Mustela ainericana), are taken in good numbers, and beavers (Castor fiber) occur more sparingly.

Minks (Putorius vison), and muskrats (Fiber zibethicus), are plentiful. These, with sliunks (Mephitis mephitica), weasels (Putorius vulgaris), and wolrerines (Gulo luscus), make up the number of the merchantable furs.

The rabbit (Lepus americanus) occurs abundantly all orer the distriet, and is, perhaps, the most useful of all to the Indians, as it affords, during the winter particularly, both food and clothing.

That the raccoon occasionally strays as far north as $N$. lat. $52^{\circ}$ is shown by the fact of one being taken by an Indian woman on the upper Attawapiskat river in 1903.

\section{Indians.}

The Indians of the district, numbering about 700 , are nomadic trappers, living principally upon fish, and obtaining from the Hudson's Bay Company, and to a smaller degree from other fur traders, the limited amount of necessaries that are not supplied by the country. A few have small huts built of logs, with fireplaces and chimneys of wattles and mud, in which they live for a part of the year, but the greater number content themselves with winter teepees constructed of poles corered with sheets of birch bark, and summer tents of cotton; indeed, house building is such an arduous task for the Indian that the traders in the district have a saying to the efiect that as soon as an Indian completes a house he dies, this result being due, not to the unwonted labour inrolred, but to the arrival of extreme old age before the work is finished. 
Petie IN

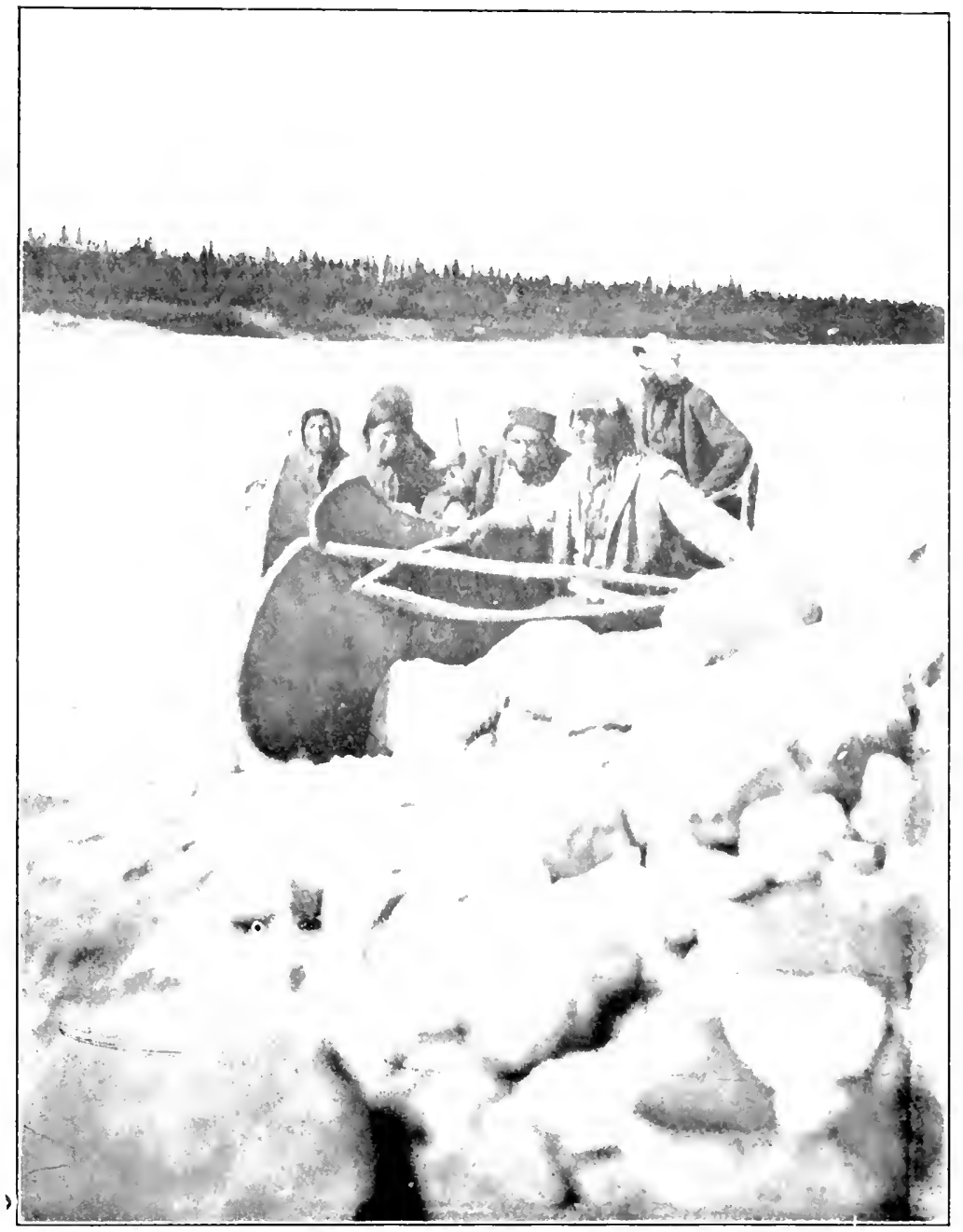

Indians of the Lewer Wini-k river.

$4074-$ p. 4 

They are of the Ojibway tribe, though mixed to a certain extent with the Crees of the Hudson Bay basin, the purest Ojibray stock being found among the bands about the herds of the rivers. The seem to be men of larger frame than the Crees of the coast.

A greater proportion of nominal Christians are found anong these Indians of the far interior than among those nearer the front, in the hinterland of Ontario. This result is due in about equal measure to the efforts of the Roman Catholic church, which maintains a permanent mission establishmerrt at Albany, with an educational home for children, and sends visiting missionary priests periodicalls among the Indians of the interior; and to the Anglican church, which maintains the missionary dincese of Moosonce, by which resident missionaries are supported at rarions points in the interior region.

The Indians seem to accept realily the forms of Christian worship, and take great pride in their proficiency in memorizing the religious formulas presented to them.

The mode of life followed by thesc Indians ofters great obstacles to the work of the missionaries, who are able to reach them fo: purposes of instruction for only short periods during each rear.

For the same reason, that is on account of their nomadic life, the teaching of the children can be carried on only in the same desultory way.

Notwithstanding these disadrantages, practically all the Indians can read and write the syllabic characters designed and introduced by James Erans, an early Wesleyan missionary among the Crees.

The introduction of this system of writing has proved a great boon to the Indians in their intercourse with one another. Written entirely phonetically it is unhampered by irregularities, and can be readily acquired by one Indian from another. So general is their knowledge of this sign language that every Indian camping-place, nud every point where canoe routes direrge, become local post offices, where letters written on birch bark, often, of course, containing only an account of trivial occurrences, but giving the opportunity to conves news of importance, are left for the information of following parties

It is very doubtful whether the Indian has advanced much in general prosperity from the days when he lired in primitive saragery. His teepee was the same then as now; his weapons are now mere 
effective, but game i- les, plentiful; he wears better clothes, or clothes that one arsoeiates with civilization, but not probably so well adapted to his need and way of living as his old raiment of skins. Even now he has to fall back upon rabbit skins, the only furs that he can afford to sacrifice to his personal use, for protection in winter. The skins are cut into strips, each skin, by being eut spirally, producing a continuous strip. These strips are sewn together at the end; and twisted into ropes which are woven loosely into blankets and rough coats that very effectually keep out the most extreme cold.

Fisl are taken with net and spear, and in trap-weirs. These arc constructed of spruce poles driven in a line into the bottom of streams, and interroren with twigs so as to fence off the greater part of the water, and force it to run in volume only through a gate arranged so that the water flowing through the opening quickly drops away through the interstices of a platform of poles, learing stranded all fish coming down with the current. One or two families will often camp by the side of one of these 'mechiken' for weeks at a time, supplying their wants entirely from the stranded fish, and smoke-drying any surplus collected. This is accomplished by simply stringing the split fish on poles and hanging them in the smoke-laden atmosphere of the teepee. The fat dropping from the fish in drying is carefully collected and preserved for future use in bags made of the skins of embryo rabbits, the bladders of pike, or in similar receptacles ingenionsly improvised from the materials at l.and

Wild rice, a staple among the Indians farther south. is too rarely met with throughout these northern regions to form any part of the Indians food supplr, and to supplement his diet of fish and flesh he has only the various berries in their seasons and the small amount of flour that he is able to buy from the trader in exchange for his surplus furs. For tea, when the imported article is not available. the small twigs of the trailing red cedar are used.

Taken as a whole, they appear to be a fairly healthy lot, though many suffer from diseases of the skin brought on probably by a too constant diet of fish. The greatest mortality is caused hy pulmonary diseases, to which they are rery prone, and to the occasional outbreals of epidemics of measles, etc., that sometimes prove widels fatal. They are far from cleanly in their personal habits, a few weeks' residence at a place in the summer time generally rendering it no longer habitable by rearon of the aremmulated filth. 
With the exception of occasional small $\log$ huts, the Indians of the region dwell in teepees covered with birch bark, though the cotton tent, made from materials bought from the traders, is now widely used during the summer months. Near the month of the Winisk river, many miles north of the ranges of white birches, a winter teepee, made after the plan generally used for birch bark wigwams, was corered with blocks of moss cut from the muskeg.

\section{Archæology.}

Chipped flints were found in numbers scattered along the beach of an island in Attawapiskat lake. Two fairly perfect arrowheads were found at the same place, one chipped from white quartz and the other from flint, derived apparently directly from the drift, where it occurs as small boulders wlich have been carried primarily from the nodular beds in the limestones of the Hudson Bay basin.

At camping-places of the Indians broken specimens of Pecten islandicus were noticed among the debris of the camps. These shells occur in a very perfect state of preservation in the marine clay, and are still used by the Indians along the river as very convenient substitutes for spoons.

\section{Forests.}

The average size of the trees growing within the country explored is not great. On exceptionally favourable tracts the spruces attain sizes quite large enough for commercial use as sawn lumber, and large areas would afford good pulpwood. Evidences of the constant recurrence of forest fires over the area are everywhere plainly seen. The brulé areas, varying from quite small patches to large tracts, are of every age; some are so old the forest has attained the full height of the old growth and the newer age of the trees can only be ascertained by a reference to their rings of growth, and others so recent that no vegetation covers the blackened surface. These fires are generally the result of the carelessness of Indian travellers, but may sometimes be traced to the igniting of a dry, standing tree-trunk by lightning. The oldest trees found in the whole area were growing on a till-covered island, about fifty miles from the mouth of the Winisk river. The complete isolation from the mainland by broad channels ensured its protection from fires having their origin outside its own borders. The spruces growing

$4071-4$ 
here were found by their rings of growth to be between 270 and 280 years old. The diameters and ages of trees, growing in a number of different localities throughout the region, wore noted, and are given in the list below:-

\begin{tabular}{|c|c|c|c|c|c|}
\hline & & & & $\begin{array}{l}\text { Dianeter } \\
\text { in } \\
\text { inches three } \\
\text { feet from } \\
\text { ground. }\end{array}$ & $\begin{array}{l}\text { Age, } \\
\text { by rings, of } \\
\text { growth. }\end{array}$ \\
\hline \multicolumn{4}{|c|}{ Tamarack, Winisk riser, 32 miles from mouth. } & 9 & 109 \\
\hline Black spruce & " & 32 & $" \quad \ldots \ldots$ & 12 & 125 \\
\hline " & " & 32 & $\ldots . \ldots$. & 12 & $1 \div 3$ \\
\hline$"$ & $" 1$ & $3 \cdot 2$ & . $\ldots \ldots$ & 8 & $\tau \overline{5}$ \\
\hline " & ." & 50 & $\ldots \ldots \ldots \ldots$ & 10 & 275 \\
\hline$"$ & $"$ & 65 & near bank.. & 8 & 130 \\
\hline " & $"$ & 65 & $"$ & 6 & 115 \\
\hline " & $"$ & (i5 5 & 10 chains hack & 3 & 105 \\
\hline Tamarack & $"$ & 65 & $" \quad$. & 3 & 80 \\
\hline Black spruce & " & belo & pikopa lake.......... & 10 & 130 \\
\hline " & $"$ & Wa & 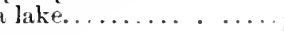 & 9 & 145 \\
\hline$"$ & " & & & 6 & 135 \\
\hline$"$ & " & Nib & $\mathrm{k}$ lake............... & 9 & 75 \\
\hline$"$ & " & & $\ldots \ldots \ldots$ & 5 & 75 \\
\hline$"$ & " & abo & oinamik lake....... & 15 & 130 \\
\hline A spen poplar & $"$ & & " $\quad \ldots \quad \ldots$ & 15 & 130 \\
\hline
\end{tabular}

The rings show that the growth is generally rapid for the period between fire and thirty sears, and afterwards exceedingly slow.

The northern limit of a number of the common trees of northern Canada falls within the district, and of one species both the northern and southern limits.

There is a black birch that the Indians call the squirrel-bark birch. Specimens of the wood and foliage of this tree were submitted to Professor John Macoun, by whom they were forwarded to Dr. Sargent, of the Arnold Arboretum, for determination. Dr. Sargent has named this birch Betula fontinalis. It was not seen growing in abundance anywhere in the district, though occasional trees were noted at various points between the Albany and Winisk rivers, the most southerly occurrence being in $\mathrm{N}$. lat. $51^{\circ} 28^{\prime}$ on Dog-hole

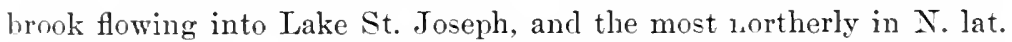
$52^{\circ} 40^{\prime}$ on the Wapitotem river flowing into Weibikwei lake on the Winisk river. The largest tree noticed had a diameter of six inches at three feet from the ground, and a height of about thirty feet. Where seen it was growing near the banks of rivers or lakes, in moist 


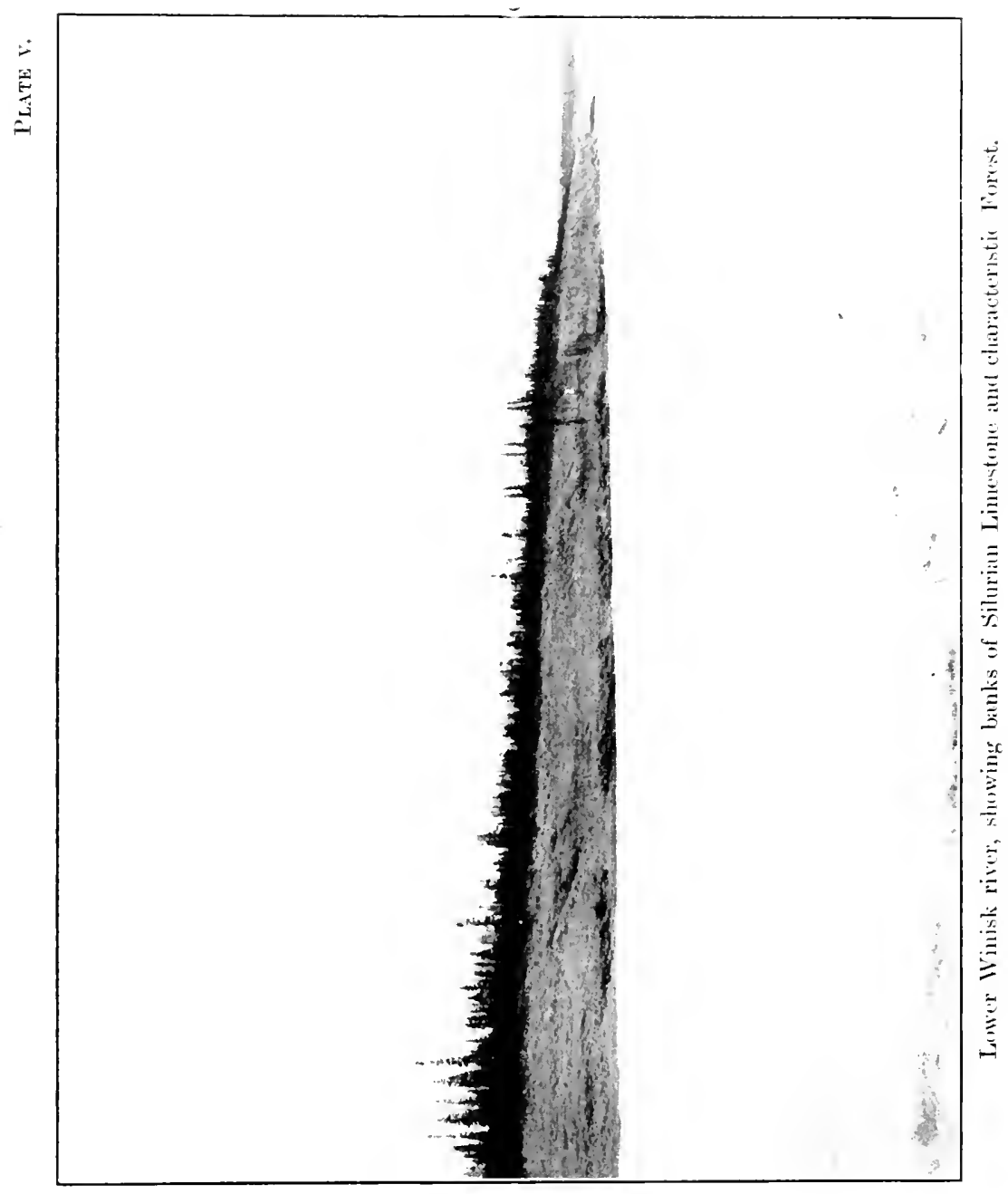

$4074-\mathrm{p} .50$. 

localities. A table is subjoined of the observed northern limits of a number of species.

\section{Northern Limits of Trees.}

White elm, Clnus americana, Albany river...... N. lat. 51 $30^{\prime}$ Black ash, Fraxinus sambucifolia, Eabemet lake... " " $51^{\circ} 50^{\prime}$ Mountain maple, Acer spicatum, between Attawapiskat and Winisk rivers........... Mountain ash, Pyrus americana, between Attawapiskat and Winisk rivers......... " $52^{\circ} 3 S^{\prime}$ Banksian pine, Pinns banksiana, Weibikwei lake.. " $53^{\circ}$ White cedar, Thuya occidentalis, Weibikwei lake.. " $53^{\circ} 05^{\prime}$ Balsam spruce, Abies balsamea, Winisk river... .. “ $54^{\circ} 15^{\prime}$ Canoe birch, Betula papyracea, Winisk river... .. “ $54^{\circ} 25^{\prime}$ Aspen poplar, Populus tremuloides, Winisk river.. “ $54^{\circ} 45^{\prime}$

The northern limits of balsam poplar, tamarack, and black and white spruce lie beyond the mouth of the Winisk river, the most northerly point examined.

\section{Climate.}

The climate, as would be expected in these latitudes, and in a wilderness country approximately a thousand feet above sea-level, is somewhat severe. The summer temperature, though on occasional days rising as high as $85^{\circ}$ Fahr., averages very much lower, and the nights are, practically, always cool. Frosty nights often continue into the early summer, and recur again in the autumn before most grain-crops would be ready for harvesting. Temperatures were taken with the thermometer during two seasons, and these, averaged, gave the following results for the months of July and August on the lower Winisk river, and for July, August and part of September on the upper Winisk and upper Attawapiskat rivers:-

$\begin{array}{llll}\text { Lower Winisk river. . . . . . . . . . . } 57^{\circ} & 69^{\circ} & 57^{\circ} \\ \text { Upper Winisk and Attawapiskat rivers. . } 47^{\circ} \cdot 5 & 61^{\circ} \cdot 6 & 55^{\circ}\end{array}$

The only points in the region where any attempts at cultivation of the land are made are the two Hudson's Bay Company's posts at Osuaburgh, near the foot of Lake St. Joseph, and at Fort Hope, on Eabemet lake.

$$
10 \div-1 \frac{1}{2}
$$


At these posts small kitchen gardens and potato-fields are maintained with some suceess, though neither place is favourably situated for the purpose, the soil in both cases consisting of an almost pure sand. Timothy and clover grow luxuriantly, and all the common garden vegetables thrive at both places. Indian corn, however, is not sufficiently filled out for table use when caught by the frost. Barley has been successfully grown at Osnaburgh, and the potato crop, wherever a suitable tract of land has been utilized, has been generally fairly good at both places.

The first killing frost in 1903 occurred on the night of September 3 , and in 1904 on the night of August 30.

The temperature of the water in a number of the larger lakes and rivers was taken by thermometer at six inches below the surface, and is given in the following, very uniform list:-

\section{Water Temperature.}

Lake St. Joseph, Albany river, June 28. . . . . . . . $591_{2}^{\circ}$ Amimwash lake, Albany river, July $5 \ldots \ldots \ldots \ldots \ldots 8^{\circ}$ Kagabades-dawaga lake, Attawapiskat river, July $16 \ldots \ldots \ldots 2^{\circ}$ Attawapiskat river, August 8............ $60^{\circ}$ Weibikwei lake, Winisk river, August $9 \ldots \ldots \ldots \ldots 2^{\circ}$ Nibinamik lake, Winisk river, August 2‥ . . . . . . . 58 Winisk river, Angust $24 \ldots \ldots \ldots \ldots \ldots \ldots 7^{\circ}$

\section{Land Shells.}

A small collection of land shells, made during the summer of 1904. has been examined by Dr. Whiteaves, who enumerated the following species. It was noted that in actual number of individuals there was a decided and progressive decrease as the latitude increased :-

Tertigo ovata, Say.

Conulus fulvus (Müller).

Zonitoides arboreus (Say).

Vitrea hammonis? (Ström).

Pyramidula striatella (Anthony).

Succinea vermeta, Say.

Succinea retusa?, Lea.

Succinea ovalis, Gould, non Say. 


\section{Freshwater Shells.}

Collections of the freshwater shells of the region were marle each year, and submitted to Dr. Whiteaves for determination, who has furnished the subjoined list, which for convenience has been tabulated according to watershed areas:-

List of Freshwater Shells collected by Mr. W. McInnes in 19034-5 on the Winisk, Attawapiskat, and Albany Rivers, on the Root and English Rivers, near Lac Seul, and on the Severn River at Trout Lake.

BY

J. F. Whitenies.

\begin{tabular}{|c|c|c|c|c|c|}
\hline & $\begin{array}{l}\text { Winisk } \\
\text { river. }\end{array}$ & $\begin{array}{c}\text { Atta- } \\
\text { wapiskat } \\
\text { river. }\end{array}$ & $\begin{array}{l}\text { Albany } \\
\text { river. }\end{array}$ & $\begin{array}{l}\text { English } \\
\text { and } \\
\text { Root } \\
\text { rivers. }\end{array}$ & $\begin{array}{l}\text { Trout } \\
\text { lake, } \\
\text { Severm } \\
\text { viver. }\end{array}$ \\
\hline Lampsilis luteola, (Lamarck). & * & * & * & & \\
\hline $\begin{array}{l}\text { Anodonta marginuta? Say.... } \\
\text { Anodonta fragilis, Ianuarck ... }\end{array}$ & * & * & & & ann. \\
\hline Anodonta Kennicottii? Lea.. & & * & * & & $\cdots \cdots \cdots$ \\
\hline phcerium simile, Sa & & * & & & $\ldots \ldots$ \\
\hline um Walker & 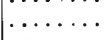 & * & $\cdots$ & & $\cdots \cdots$ \\
\hline pherium enarginatum, Prime. & & * & $\cdots$ & & $\cdots \cdots$ \\
\hline pharium stum & & * & .. & . & ... $\cdot$ \\
\hline 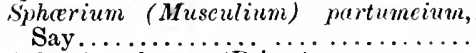 & & * & & & \\
\hline Sphcerium flavu & & & $*$ & & $\cdot \cdots$ \\
\hline Sphat & & & & $\cdots$ & \\
\hline Spherium striatime & & & . & * & $\cdots \cdots \cdots$ \\
\hline$u m-$ & * & $\ddot{*}$ & $\cdots$ & & $\cdots \cdots \cdots$ \\
\hline $\begin{array}{l}\text { Pisidium eompr } \\
\text { Pisidium altile, }\end{array}$ & & & & & $\cdots \cdots$ \\
\hline$m$ fallax, var. erians, Sterki.... & $\cdots$ & & & & $\ldots \ldots$ \\
\hline num varialile, Prime .. .......... & $\ldots \ldots$ & * & & & $\cdots \cdots$ \\
\hline$m$ affine, Sterk & $\ldots \ldots \ldots$ & * & $\cdots$ & $\ldots$ & $\cdots$ \\
\hline Pisidium Sargenti, S & $\cdots$ & & * & & $\cdots$ \\
\hline Pisidinm Mainense, Sterki............. & & & * & & $\cdots \cdots \cdots$ \\
\hline $\begin{array}{l}\text { Pisidium abditum, Haldeman......... } \\
\text { Pisidium Roperi, Sterki............. }\end{array}$ & & & * & & $\ldots \ldots$ \\
\hline Pisidium polit & $\ldots \ldots \ldots$ & . & $\cdots$ & & \\
\hline Pisidium rotundatum, $\mathrm{Pr}$ & $\ldots \ldots$ & . & & & 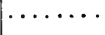 \\
\hline 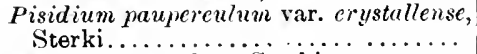 & & & & & \\
\hline Pisidium ves & & & & & \\
\hline Pisidium spl & & & * & & \\
\hline Pisidium seutellatum, Sterki........ & " & & & & - \\
\hline $\begin{array}{l}\text { Pisidium median } \\
\text { Pisidium nilium }\end{array}$ & $\cdots$ & & & & \\
\hline $\begin{array}{l}\text {, Held, Small var } \\
\text { ?................ }\end{array}$ & & & & & . $\ldots$ \\
\hline -? (near P.a & & & & & \\
\hline
\end{tabular}




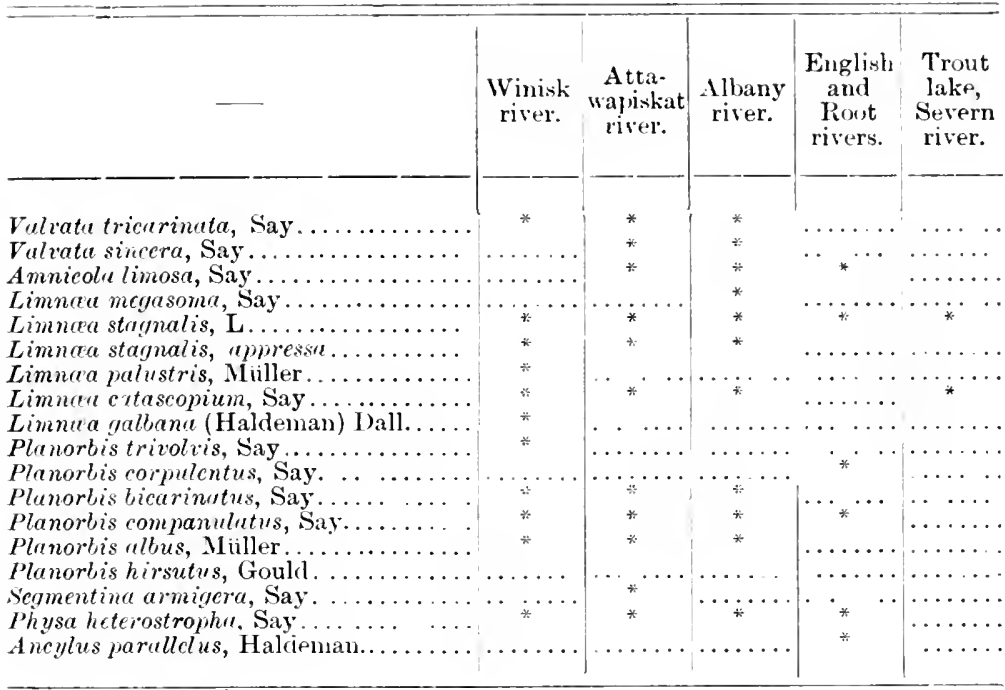




\section{N D $\mathbf{X}$.}

A

I.:T.

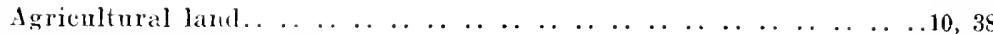

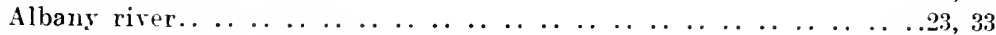

Animals, wild, of the ristrict.. . . . . . . . . . . . . . . . . . . . . 45

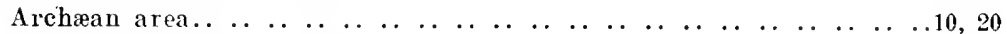

$\begin{array}{llllllllllllllllllllllll}\text { Archæology. } & \ldots & \ldots & \ldots & \ldots & \ldots & \ldots & \ldots & \ldots & \ldots & \ldots & \ldots & \ldots & \ldots & \ldots & \ldots & \ldots & \ldots & \ldots & \ldots & \ldots & 49\end{array}$

Arrowsmith map, details for, supplied by G. Taylor.... . . . . . . .

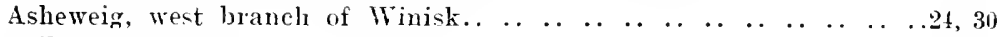

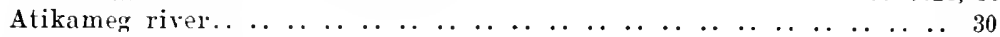

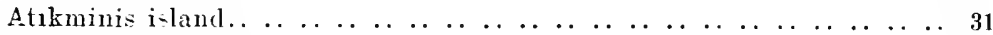

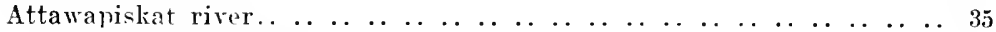

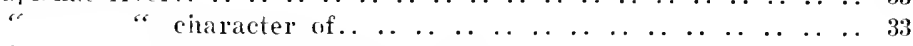

" " descended by Dr. R. Bell.....................

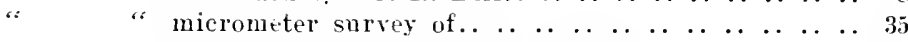

" $"$ probable connexion with Albany river.. $\quad . \quad \ldots \quad \ldots \quad . \quad 23$

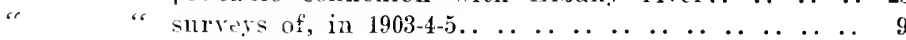

B

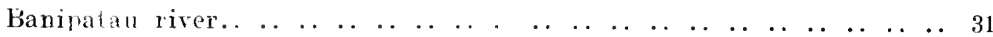

Bell, Dr. Robert, deccencied Ittawapiskat river... . . . . . . . . . . . 8 "c past coast Hudson bay.. report on Iansdowne lake and Attawapiskat rirer. 38 route between Albany and Ittawapiskat river, tra-

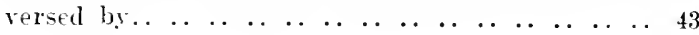

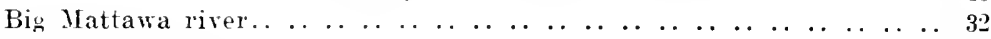

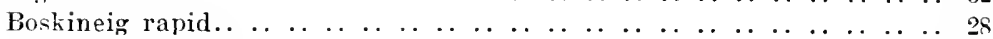

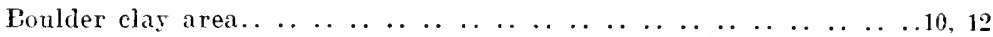

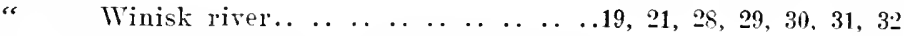

Bcyä, W. H., Ekwan and Trout river explored by. . . . . . . . . s

\section{C}

Camsell, Chas., drift masses noted by. . . . . . . . . . . . . . . . . . 25

Caribon island (See Atikminis).. $\ldots \begin{array}{lllllllllllllll} & \ldots & \ldots & \ldots & \ldots & \ldots & \ldots & \ldots & \ldots & \ldots & \ldots & 31\end{array}$

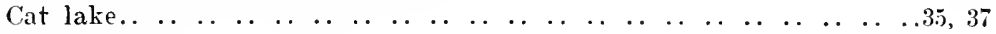

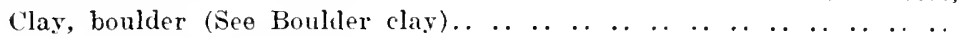

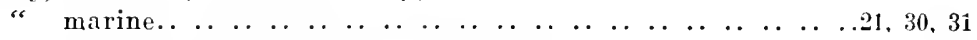

“ specimens examined by Dr. Hoffmann.. . . . . . . . . . . . . 38

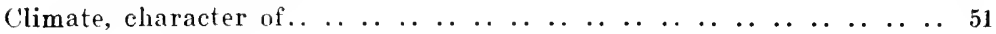

\section{D}

Dowling. D. B., Ekwan and 'Trout rivers explored by... . . . . . . . $\mathrm{s}$ rocks at Sutton Mill lake noted by... . . . . . . .18, 32 


\section{E}

Page.

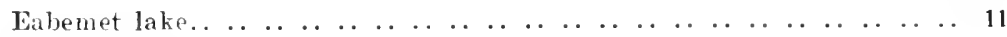

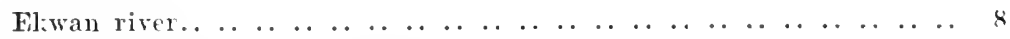

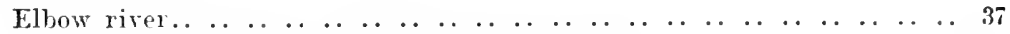

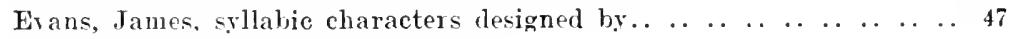

Explorations, early, in the district.. $\ldots \ldots \ldots \ldots \ldots \ldots$

\section{F}

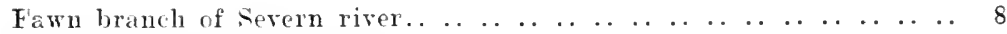

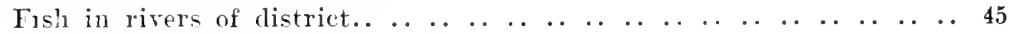

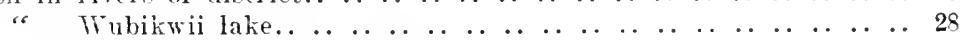

Fishbasket river (See Michikenopik)..

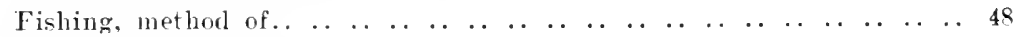

Food of the Indians.. $\ldots \begin{array}{llllllllllllllllllll} & \ldots & \ldots & \ldots & \ldots & \ldots & \ldots & \ldots & \ldots & \ldots & \ldots & \ldots & \ldots & \ldots & \ldots & \ldots & 48\end{array}$

Forests (See also timber). .

Fort Hope, lieadquarters of II. B. trade.. $\ldots \ldots \ldots \ldots \ldots \ldots$

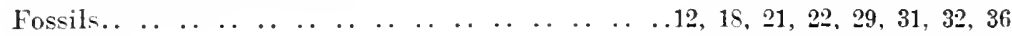

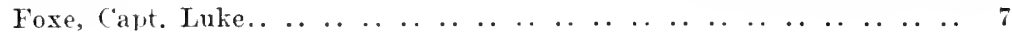

\section{G}

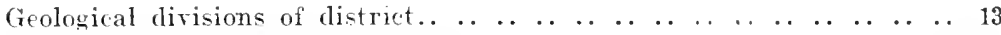

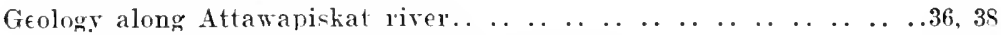

- between Albany and Attawapickat rirers.. . . . . . . . . . 43

$"$ " $"$ Attawapiskat and Winisk rivers. . . . . . . . . .40, 41

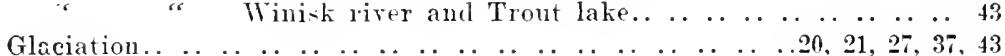

\section{H}

Foffmann, Dr., examination of clays.. $\ldots \ldots \ldots \ldots \ldots$

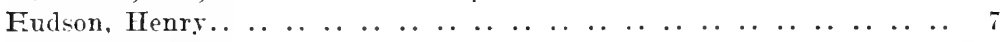

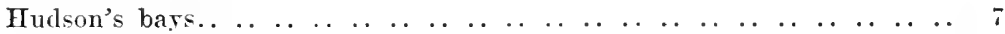

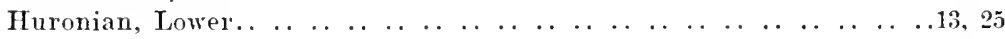

I

Irdians. .

$J$

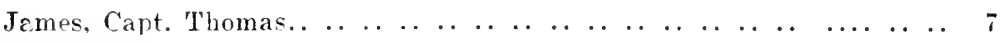

\section{K}

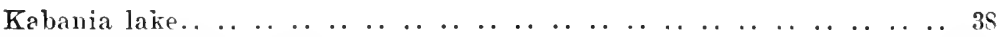

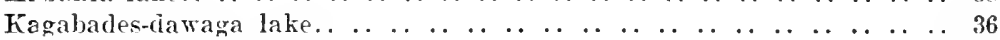

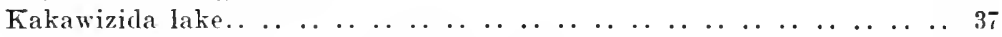

Kanuchuan branch of Attamapiskat ricer.. $\ldots \begin{array}{ccccccccc} & \ldots & \ldots & \ldots & \ldots & \ldots & \ldots & \ldots & 35\end{array}$

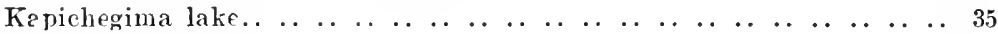

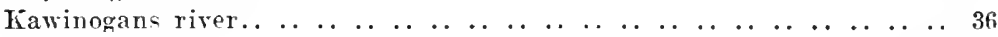

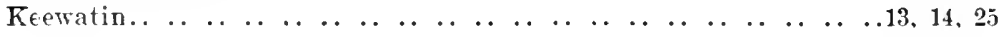




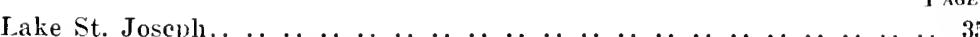

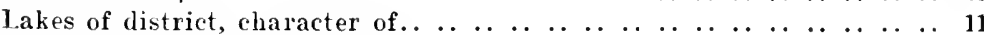

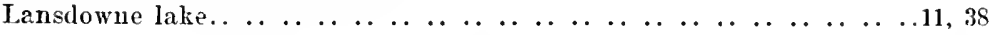

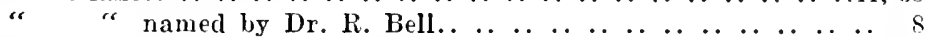

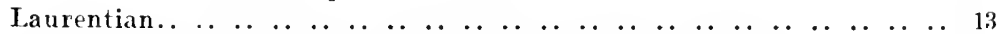

I.ow, A. P., character cf country on Fawn branch of Severn ....... 18 Fawn branch of Severn river explored by.......... . 8

M

Mattawa river..

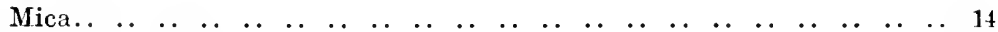

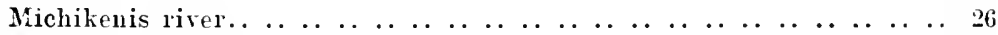

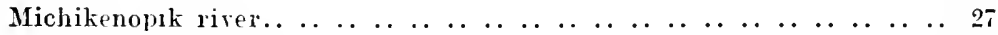

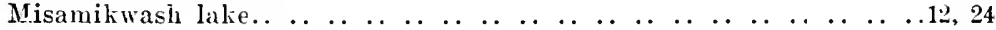

Mishamattawa rirex..

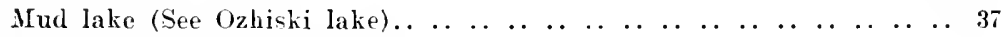

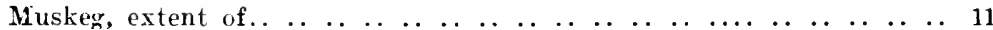

$\mathbf{N}$

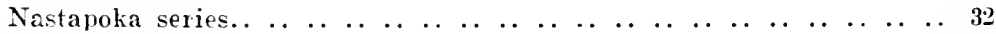

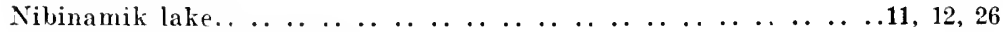

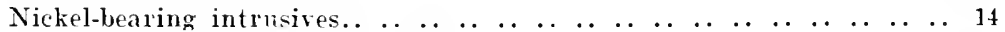

No-Pickerel river (See hawinogans)..

Northwest passage..

\section{O}

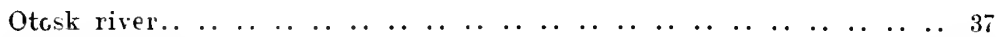

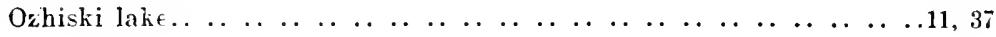

$\mathbf{P}$

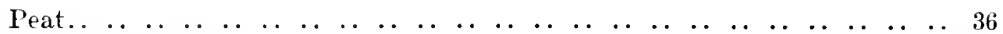

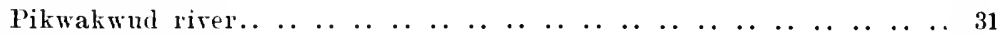

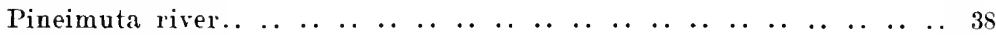

Pleistocene..

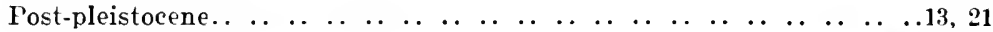

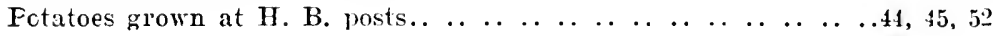

R

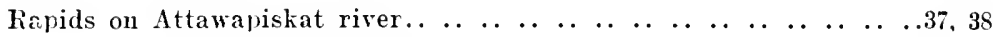
canoe route Winisk river to Trout lake.. ... ... ...42, 43

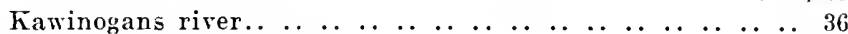

“ Marten Drinking river..

“ Winisk river.. $\ldots \ldots \ldots \ldots \ldots \ldots \ldots$

Rice, wild, rarely met with.. . . . . . . . . . . . . . . . . . 4s

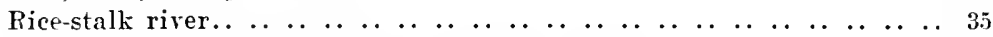

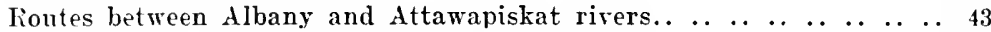

" " Attawapiskat and Winisk rivers..

" $\quad$ Winisk river and Trout lake..

" into the region. . . . . . . . . . . . . . . . . . . . . . . . 
Gargent, Dr., birch naned by.......................... 50

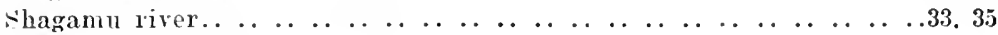

Shamaltawa river.. $\ldots \ldots \ldots \ldots \ldots$

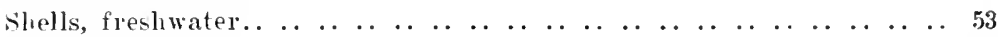

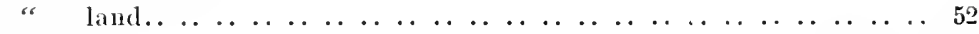

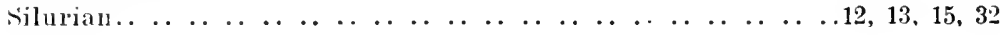

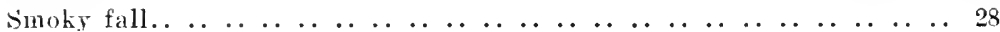

$T$

Tabisokwia branch of Winisk river..................23, 28, 30

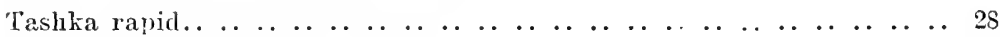

'laylor, G., visited Winisk river. . . . . . . . . . . . . . . . . . . 8

Temperature of water.. $\ldots \ldots \ldots \ldots \ldots \ldots$

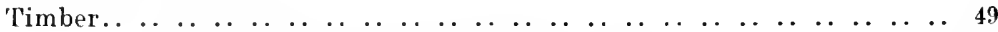

" between Attawapiskat and Winisk rivers...

" " Winisk river and Trout lake............ . . . .42, 43

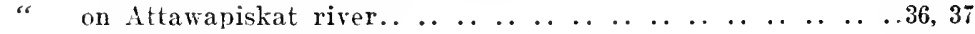

" " Nibinimak lake.. $\ldots \ldots \ldots \ldots \ldots \ldots$

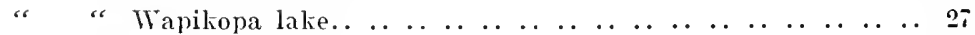

" " Weibikwei lake..

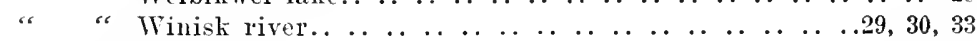

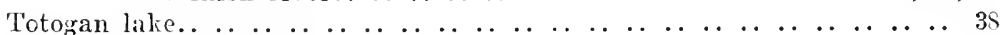

Trees, northern limit of. . . . . . . . . . . . . . . . . . . . . . . . . 51

Treut river.. $\ldots \ldots \ldots \ldots \ldots \ldots$

\section{V}

Vegetables, garden, possibility of raising... . . . . . . . . . . 44,51

V.getation along Winisk river.. $\ldots \ldots \ldots \ldots \ldots$

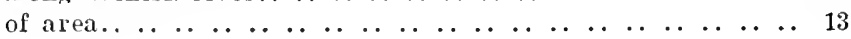

\section{W}

Wapikopa lake. $\ldots \ldots \ldots \ldots \ldots \ldots \ldots \ldots \ldots$

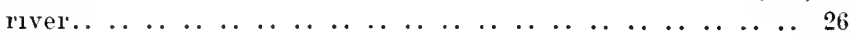

Wapitotem $\operatorname{river} . \ldots \ldots \ldots \ldots \ldots$

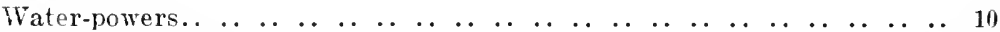

Weibikwei lake.. $\ldots \ldots \ldots \ldots \ldots$

Th hiteaves, Dr., fossils identified.. . . . . . . . . . . . . . .18, 22, 32

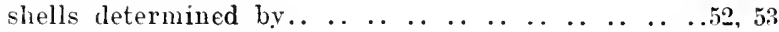

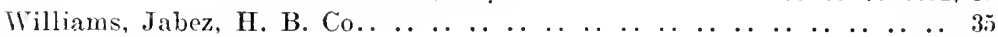

Wimbobika lake.. $\ldots \ldots \ldots \ldots \ldots \ldots \ldots$

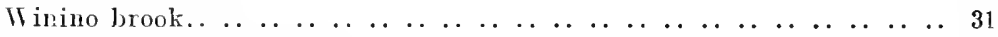

Winisk river, character of.. $\ldots \ldots \ldots \ldots \ldots \ldots$

estuary of .. $\ldots \ldots \ldots \ldots \ldots \ldots$

length and volume... $\ldots \ldots \ldots \ldots \ldots$

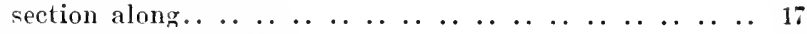

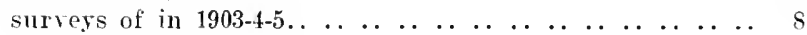

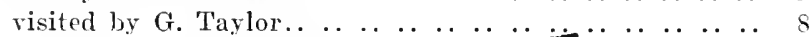
missionaries..

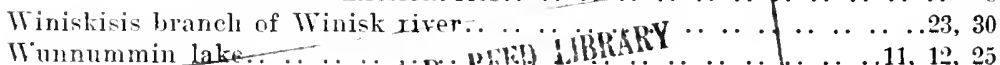

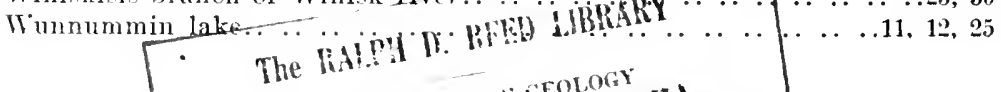

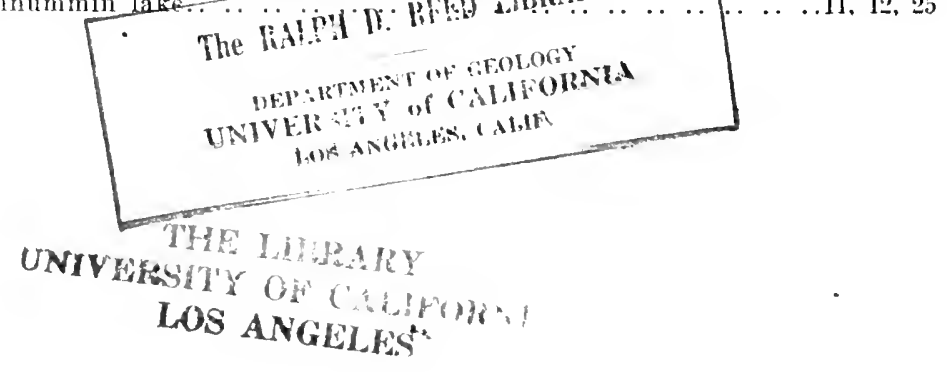




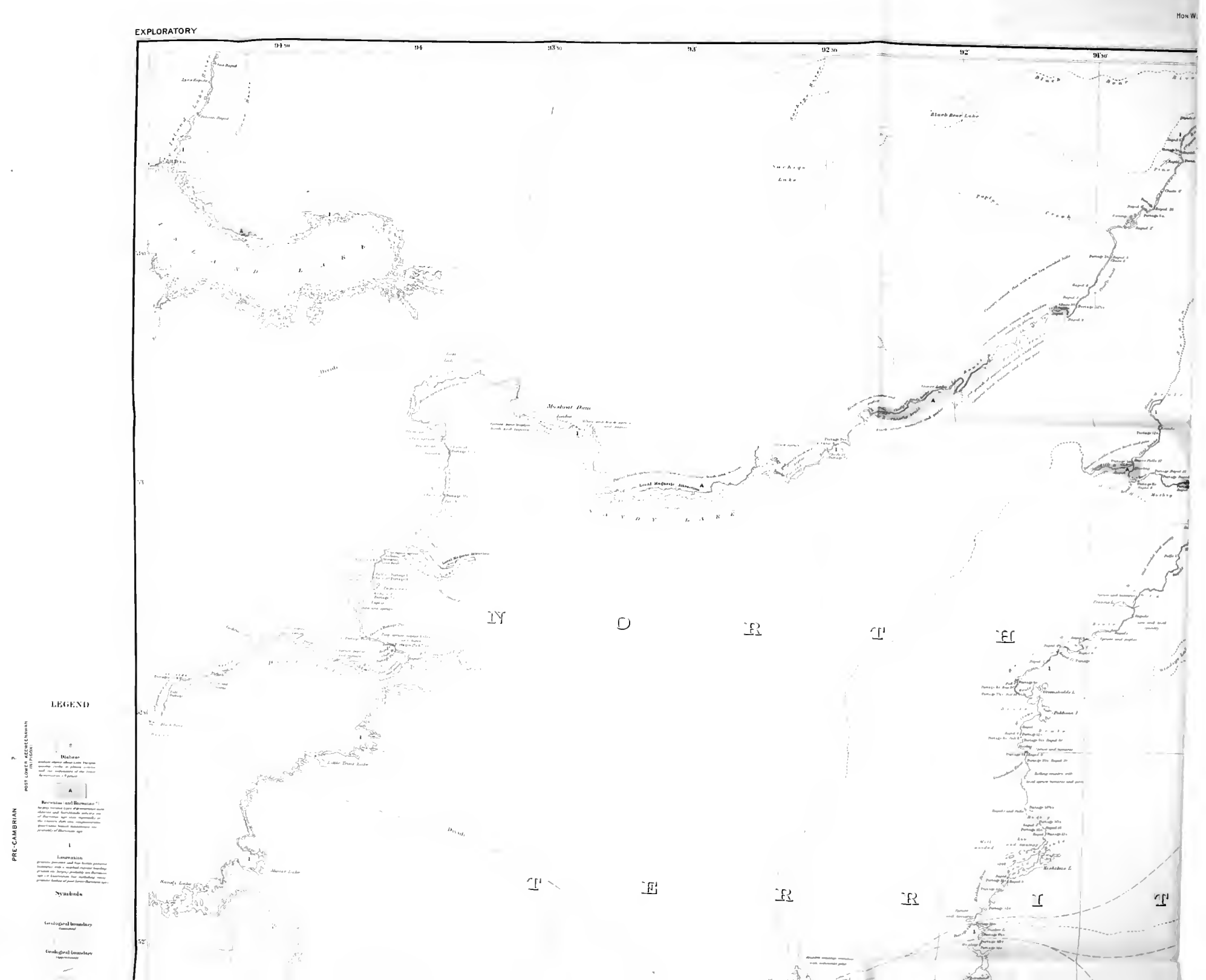


Connia

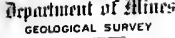

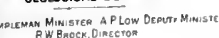

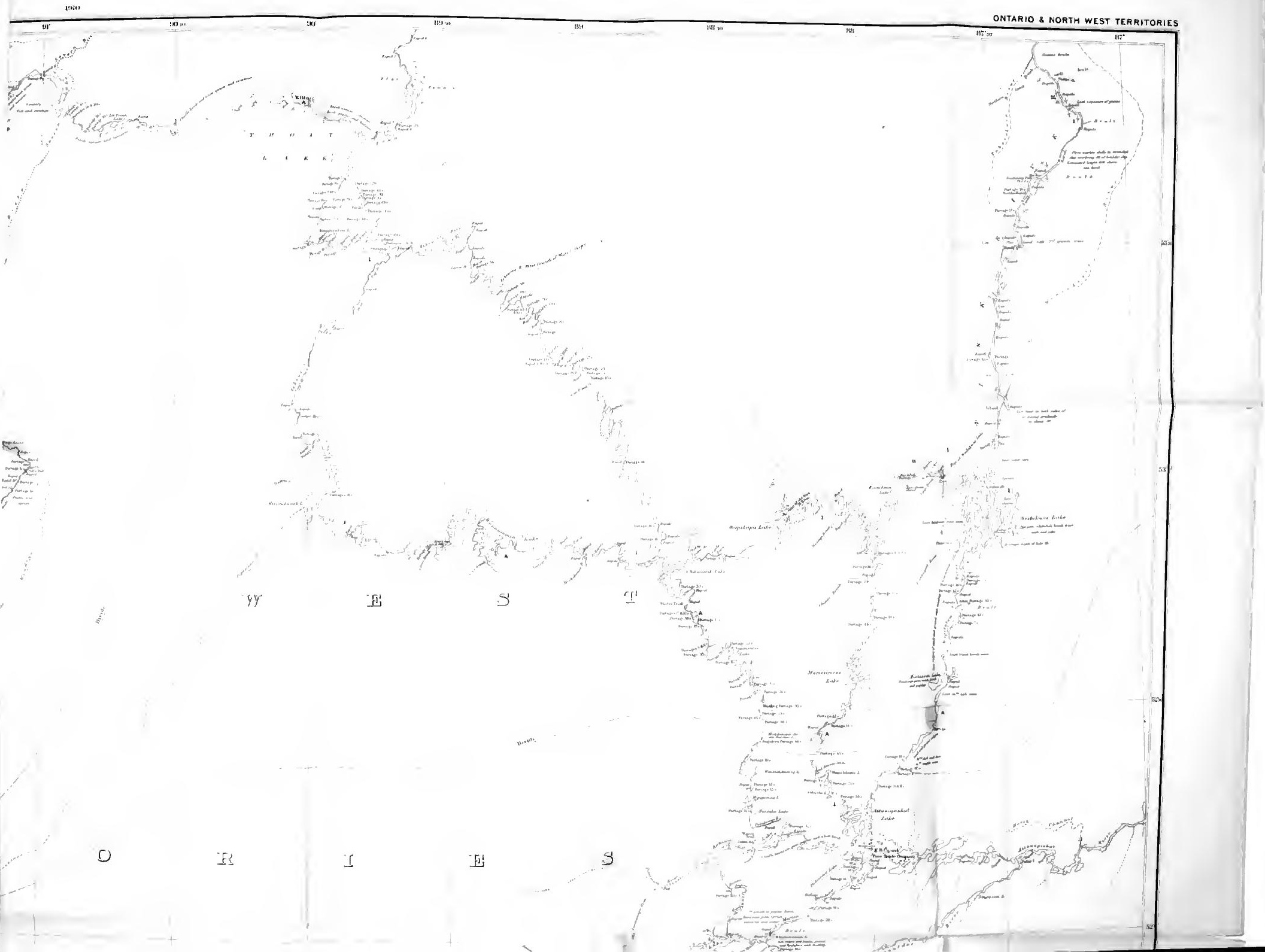




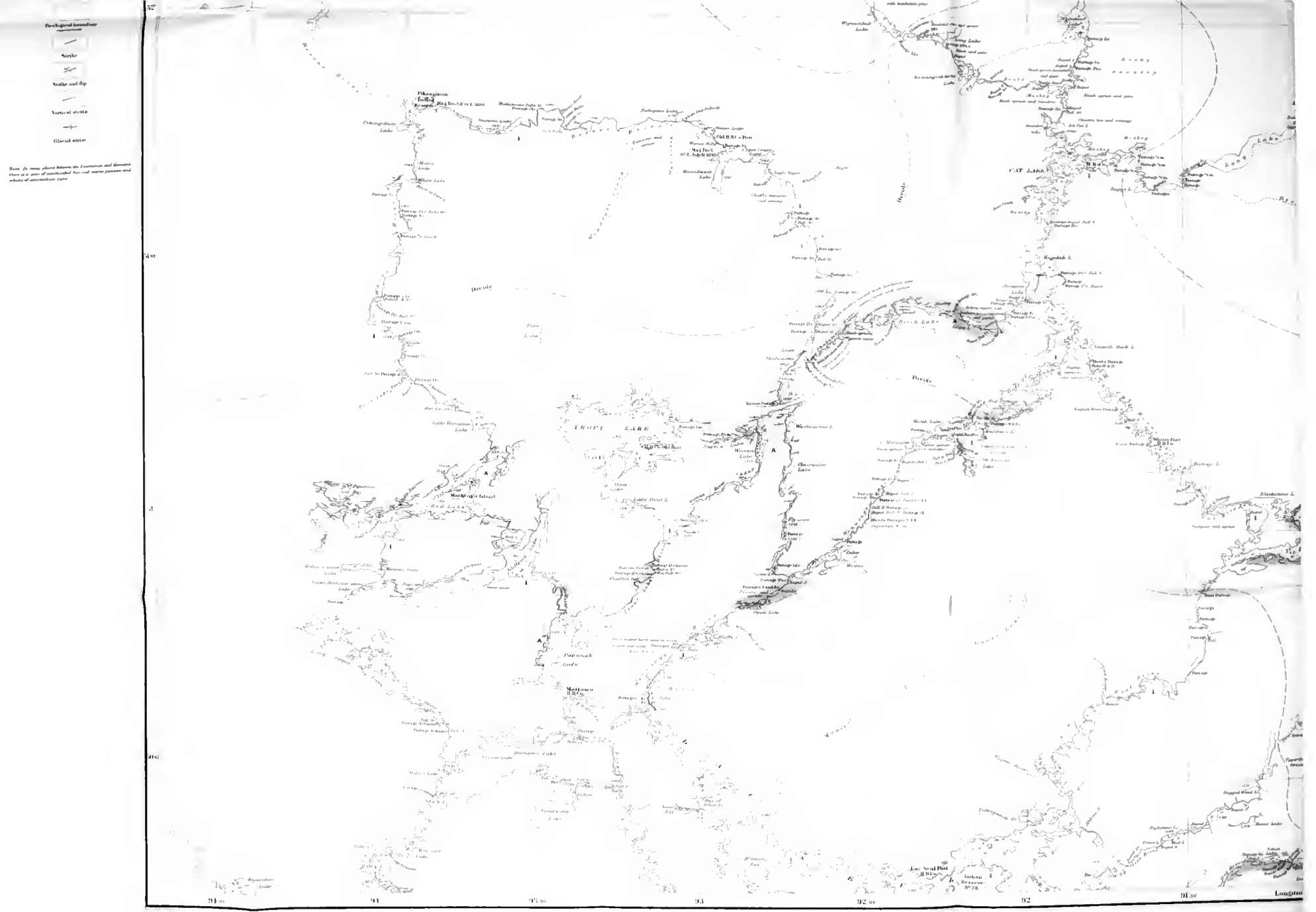

MABAYY, SHVYAL

NokTtIRK oNTLN 


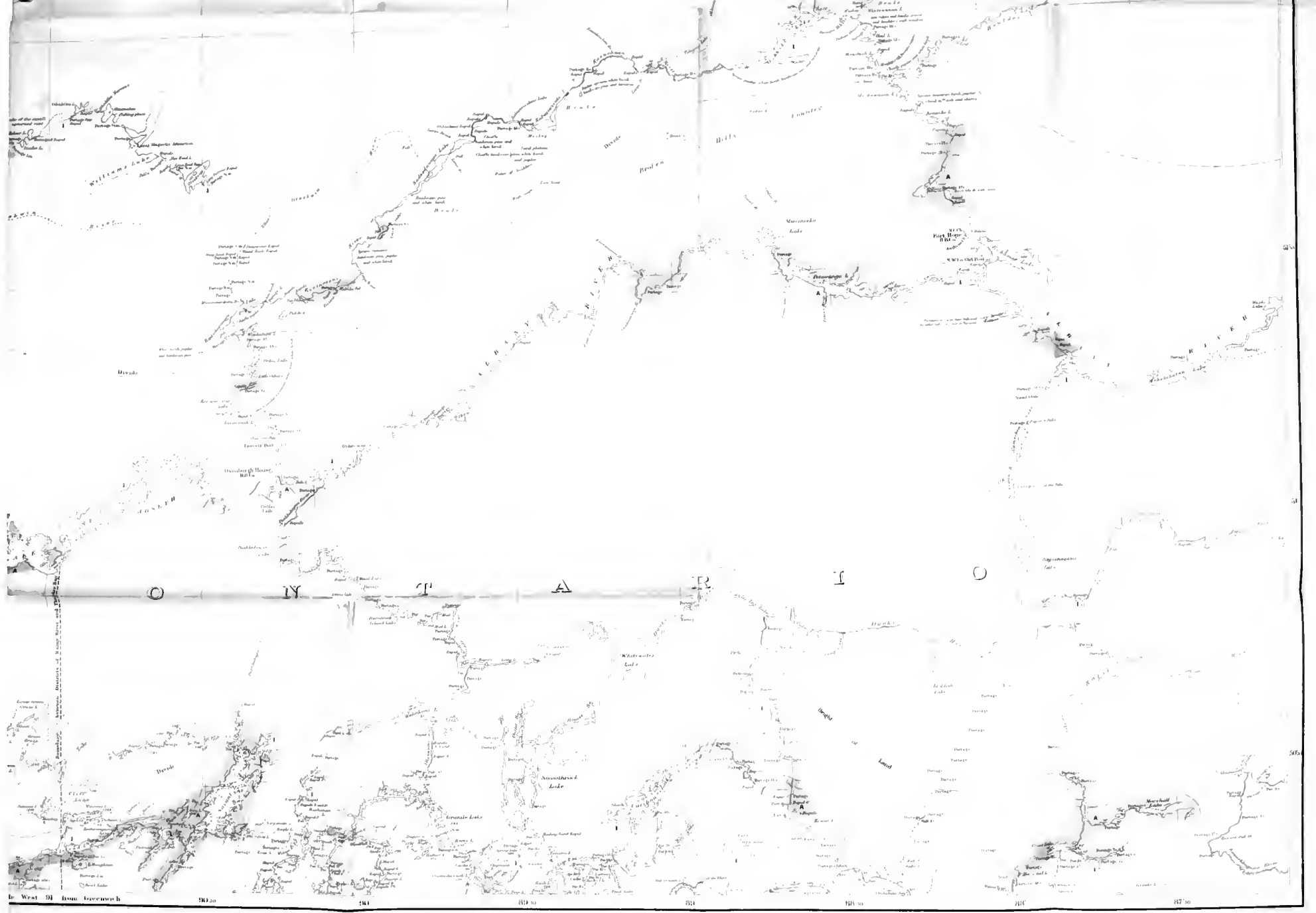

MAP :AS

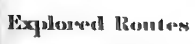

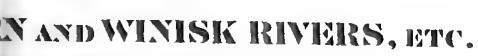

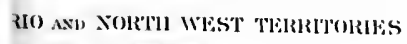

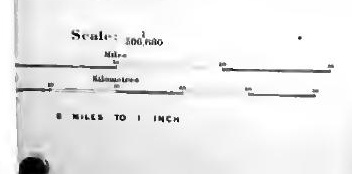

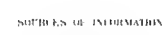

and

ind

$+=$ 
UC SOUTHERN REGIONAL LIBRARY FACILITY

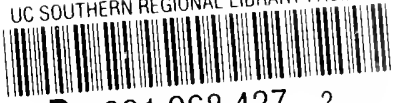
D 0010684272 


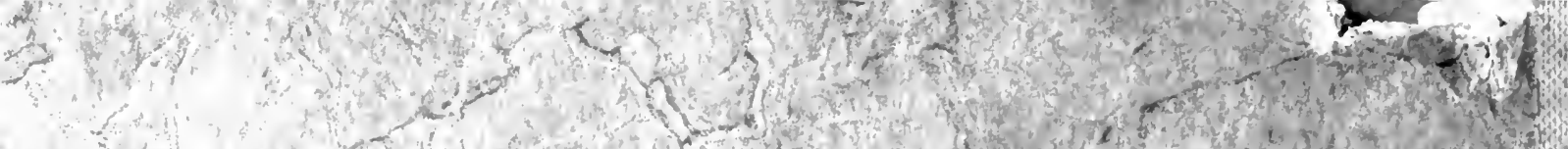

W

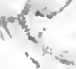

in

(y)

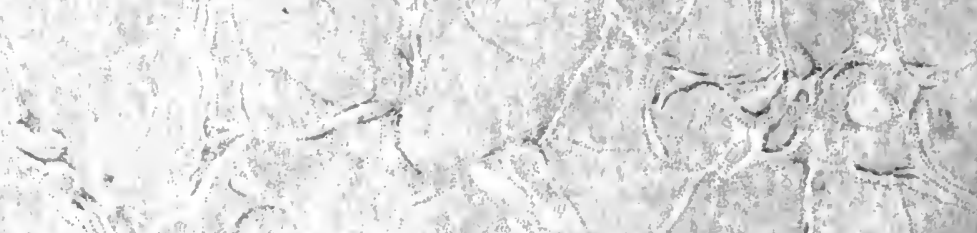

$3+6$

$-\infty$

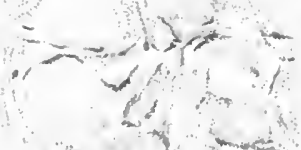

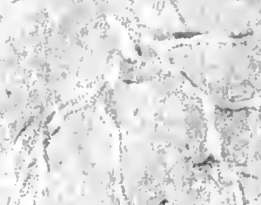

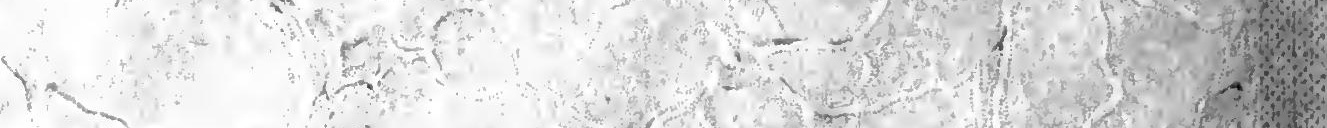

$x+4$

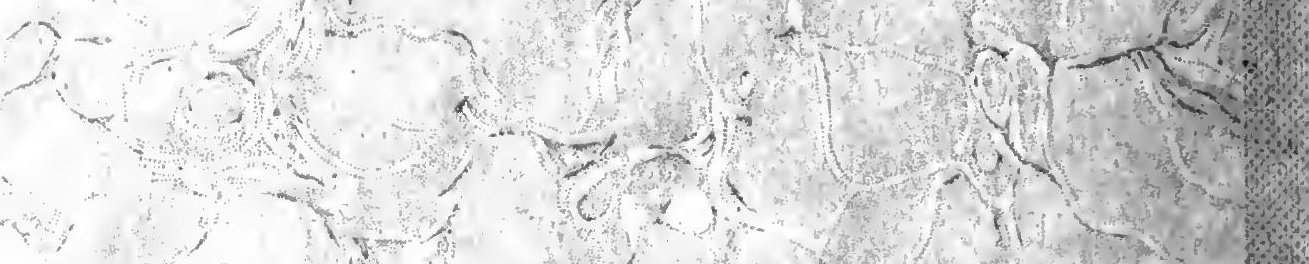

$-2$

(3.

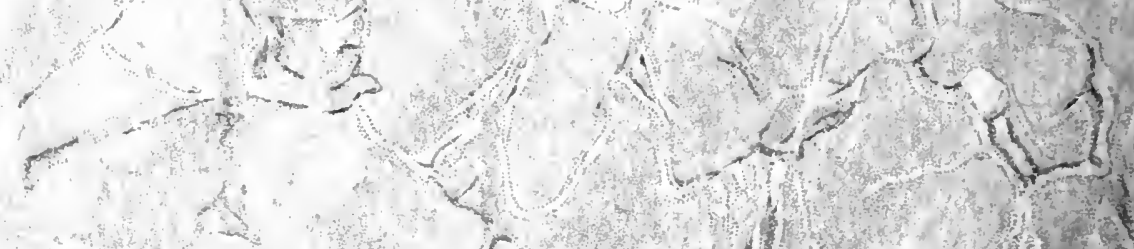

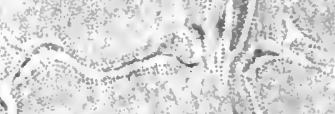

$\left(-1+x^{2}\right.$ (3) 